v. 11, n. 1

Vitória-ES, Jan.-Feb. 2014

p. 111 - 129 ISSN 1808-2386 DOI: http://dx.doi.org/10.15728/bbr.2014.11.1.6

\title{
The Influence of information asymmetry on the return and volatility of value and growth stock portfolios
}

\author{
Max Leandro Ferreira Tavares ${ }^{\dagger}$ \\ IBMEC \\ Claudio Henrique da Silveira Barbedo ${ }^{\Omega}$ \\ IBMEC and Central Bank of Brazil \\ Gustavo Silva Araujo \\ Central Bank of Brazil
}

\begin{abstract}
This article investigates whether the information asymmetry component imbedded in the bidask spread helps explain the difference in returns between portfolios composed of value versus growth stocks in the Brazilian market. Additionally, we test whether the portfolios' volatility has any relation with asymmetry. In this way, we incorporate an element from the market microstructure literature, the information asymmetry component, in the classic asset pricing theory. The results obtained for the period between July 2006 and April 2009 suggest that asymmetry can explain the difference in returns of the two types of portfolios.
\end{abstract}

Keywords: Value stock portfolios, growth stock portfolios, information asymmetry.

* Author for correspondence:

${ }^{\dagger}$. MSc in Economics from IBMEC Institution: Professor at IBMEC Address: Rua: Mem de Sá, 81, apt. 505, Niterói, Rio de Janeiro - RJ - Brazil E-mail: mleandro@eletros.com.br Telephone: (21) 2179-4727

\footnotetext{
${ }^{\Omega} \mathrm{PhD}$ in finance from COPPEAD/UFRJ Institution: Assistant Professor at IBMEC and researcher with the Central Bank of Brazil. Address: Rua: Aquidabã, 431, Méier

Rio de janeiro - RJ - Brazil

E-mail: cbarbedo@ibmecrj.br

Telephone: (21) 2189-5565
}

\footnotetext{
${ }^{¥} \mathrm{PhD}$ in economics from $\mathrm{EPGE} / \mathrm{FGV}$ Institution: Central Bank of Brazil Address: Praia de Botafogo 528, Botafogo, Rio de Janeiro - RJ - Brazil E-mail: Gustavo.araujo@bcb.gov.br Telephone: (21) 2189-5075
} 


\section{INTRODUCTION}

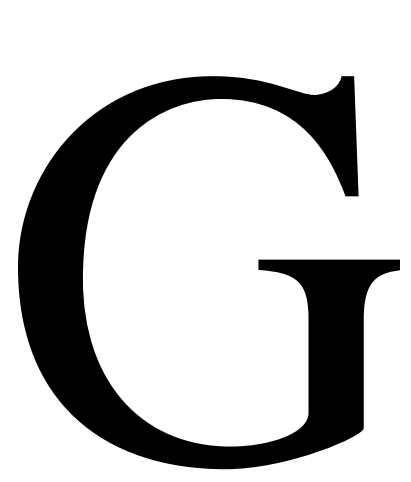

rowth stocks are defined as those of firms with low ratio between book value and market value. At the opposite extreme, shares of firms with high book-to-market ratio are classified as value stocks. The international financial literature converges in finding that value stocks produce greater returns than do growth stocks, even when the returns are adjusted for the usual risk measures. ${ }^{i}$ In the Brazilian market, various studies have reached the same conclusion regarding the superiority of value stocks and have found lower risk of these assets in comparison to growth stocks. ${ }^{\text {ii }}$

Despite this consensus about the performance of value against growth stocks, the reasons for that superiority have not yet been fully explained in the literature. According to Fama \& French (1993), the differential return between value and growth stocks can be explained as a premium for the risk not captured by the capital asset pricing model (CAPM). Therefore, the criticism falls on the explanatory power of the CAPM's beta. Lakonishok, Shleifer \& Vishny (1994) suggested explanations related to investor behavior and the cost investors incur in selecting shares for their portfolios. In turn, Kothari, Shanken \& Sloan (1995) suggested that methodological problems of sample selection are the cause. More recently, Yu (2011) affirmed that market characteristics that hamper asset price correction, such as limitations on short selling, cause a beneficial effect for value stocks to the detriment of growth stocks, helping to explain the phenomenon. Gulen, Xing \& Zhang (2011) demonstrated that this premium paid for value stocks is sensitive to macroeconomic conditions and variations in time. In Brazil, Holloway (2012) showed that funds that invest in value stocks obtain greater return and incur lower risk than funds that invest in shares composing the Ibovespa. These studies not only have great academic value, they also help in the formulation of investing strategies by asset managers and professionals of institutions. The objective of this study is to investigate whether the information asymmetry component embedded in the bid-ask spread helps explain the difference in performance between these two types of shares. Additionally, we test whether the portfolios' volatilities are related to this component.

Akerlof (1970) presented information asymmetry as one of the main market failings. Information asymmetry occurs because prospective buyers of goods generally do not have the same information as the owners. In the corporate setting, this means that managers have more and better information than do investors. This failing upsets the balance of the market, 
affecting the decisions of agents for the efficient allocation of resources. Various studies have related information asymmetry and the spread between the offers to buy and sell stocks. The greater the asymmetry and the lower the liquidity of the stock, the higher this spread is. Amihud \& Mendelson (1989) found evidence in the American stock market that the return of equities is negatively related to this spread, a phenomenon that can be attributed to the existence of a liquidity premium in the market. Stoll (1989) consolidated the presence of the information asymmetry component when stating that the literature covers three costs built into the bid-ask spread to which traders are subject: (i) order processing costs; (ii) inventory holding costs; and (iii) adverse selection costs (the information asymmetry component). He modeled the decomposition of this spread using daily data of prices and the spreads of shares listed on the NASDAQ/NMS, concluding that on average order processing accounts for $47 \%$ of the spread, while $10 \%$ comes from the holding costs and $43 \%$ refers to the information asymmetry component.

According to Araújo et al. (2010), there are two classes of models to estimate the bidask spread. The first approach, initially proposed by Roll (1984), uses properties of the serial covariance of stock returns. By the second approach, inferences about spread are made based on regressions in which the independent variables are based on an indicator of the direction of the trade that identifies whether the transaction is initiated by a buy or sell order (GLOSTEN; HARRIS, 1988). Although covariance models can be adapted to determine the components of the spread (GEORGE et al., 1991; STOLL, 1989), the method based on the trading direction is more suitable for this purpose. ${ }^{\text {iii }}$ Huang \& Stoll (1997) followed the second approach and constructed a general model to decompose the three spread components. The results indicated an average of: (i) $61.8 \%$ for order processing costs; (ii) $28.7 \%$ for holding costs; and (iii) 9.6\% for the adverse selection component. Besides this, based on data from 19 large firms listed on the NYSE, they concluded there is a significant variation of the components of the spread in function of the order size.

This article contributes to the literature by associating the information asymmetry component with asset pricing theory. To our knowledge, this is the first work that links the market microstructure to the pricing of value and growth stock portfolios. For this purpose, we incorporate information asymmetry data to the returns of value and growth stock portfolios for the purpose of measuring its impact on these investment strategies. The hypothesis tested is that the difference in returns between portfolios formed by value stocks 
and those composed of growth shares is related to the difference of information asymmetry in the bid-ask spreads of the two portfolio types.

The other hypothesis tested is that the volatility of the portfolios' return is related to the degree of information asymmetry associated with the stocks that compose them. Although this relation at first glance seems intuitive, companies with more volatile cash flows do not necessarily have greater information asymmetry. For example, a firm with highly volatile cash flows can be sufficiently transparent to the point that the information asymmetry regarding investing in its shares is small. The results evidence the influence of information asymmetry on the daily returns of value and growth portfolios and indicate that the greater the information asymmetry, the more volatile their returns are.

The article is divided into three more sections. In the second we present the sample and describe the methodology, while in the third we present and discuss the results, before summarizing the conclusions in the fourth section.

\section{DATABASE AND METHODOLOGY}

\subsection{DATABASE}

Our data set is composed of the shares traded on the BM\&FBovespa without a market maker. ${ }^{\text {iv }}$ To select the portfolios, we used the Economática database for information on price, equity value and market value. The composition of the Ibovespa was obtained from the BM\&FBovespa website and the information on the bid-ask spread as well as the information asymmetry component (in percentage of the spread) was obtained from an adaptation of the first version of the model proposed by Huang \& Stoll (1997) for stocks without a market maker. ${ }^{\mathrm{v}}$

To obtain the spread and asymmetry data, we extracted the trade initiation sequence from the database provided by the BM\&FBovespa. This base is not regularly available from database services. The extraction of this sequence was only possible because the base is composed of three distinct parts. The first contains the buy offers, with the date of the trading session and the timing to the nearest second, the stock, sequence number of the offer, date of inclusion and validity of the offer (if there was some type of alteration) and the number of the modified offer. The second part contains sell offers, with the same data is in the first part. The third part contains information on trades realized. This part is composed information on the date, stock, trading number, trading price, quantity sold, date of the buy order, date and sequence of the sell offer and timing of the trade to the second. The sample covers the period 
from July 2006 to April 2009 for a total of 97 stocks. The information asymmetry data are presented as a percentage of the spread.

\subsection{METHODOLOGY}

According to Stoll (1989), there are three components embedded in the bid-ask spread of financial assets: (i) order processing costs; (ii) inventory holding costs; and (iii) adverse selection costs (information asymmetry component). The relative importance of the spread components was estimated by applying the first version of the model of Huang \& Stoll (1997), with no holding cost, since the stocks in our sample do not have any market makers. The model is based on an indicator of the trading direction. We use our own notation to describe the model, based on the works of Glosten (1987), Glosten \& Harris (1988) and Huang \& Stoll (1997).

To construct the value and growth portfolios, we followed the method of Fama \& French (1992), and because of the Brazilian setting, the work of Costa Jr., Picanço \& Ramos (2000). In each period, we formulated value portfolios composed of the ten stocks with highest ratio between book value and market value (BV/MV), and growth portfolios comprised of the ten stocks with the lowest ratio. From the sample of shares made available by the BM\&FBovespa, we selected those that compose the Ibovespa, given the higher liquidity of these papers in relation to the Brazilian market in general. The composition for June 2006 was used as a reference to form the first portfolios. As of September 2006, the portfolios were rebalanced every four months, according to the new data on BV and MV disclosed by the companies. This process was repeated until formation of the last portfolios. Therefore, we constructed value and growth portfolios in nine four-month periods (three years), the first being July to August 2006. The alterations of the portfolios formed in the following periods occurred on the same dates of alteration of the theoretical portfolio of the Ibovespa.

\subsubsection{Model of Huang \& Stoll (1997)}

To estimate the information asymmetry coefficient, we used the model of Huang \& Stoll (1997), which is based on the direction of trading. Models based on trade direction assume that the bid and ask prices are the result of competition among all participants in the market (Glosten, 1987). There is no assumption that the bid and ask prices represent quotations from a single individual, i.e., this type of model can be used for stocks without market makers. 
Let $p^{*}$ be the value of the asset if all agents had access to inside information, and suppose that the risk of private information is not priced. Therefore, the true price, based on all the generally known information $(H)$, is $p=\mathrm{E}\left[p^{*} \mid H\right]$.

Assuming that investors in general only have the information available to all other investors, we can define the functions $a($.$) and b($.$) :$

$$
\begin{aligned}
& a(x)=\mathrm{E}\left[p^{*} \mid H, \text { "investor buys at } \mathrm{x}^{\prime \prime}\right] \\
& b(\mathrm{y})=\mathrm{E}\left[p^{*} \mid H, \text { "investor sells at } \mathrm{y}\right]
\end{aligned}
$$

The functions $a(x)$ and $b(y)$ describe how the available information is updated to include the most recent transaction.

Let $Z A=a(A)-p$ and $Z B=p-b(B)$, where $A$ and $B$ are, respectively, the ask and bid prices. Then $Z_{A}+Z_{B}$ is part of the spread due to the belief that there are informed investors. Therefore, $A(A S K)$ and $B(B I D)$ can be written in the following form:

$$
\begin{aligned}
& A=a(A)+C_{A}=p+Z_{A}+C_{A} \\
& B=b(B)-C_{B}=p-Z_{B}-C_{B},
\end{aligned}
$$

where $C_{A}$ and $C_{B}$ are the order processing costs. The spread, $S=A-B$, is given by $Z_{A}+$ $Z_{B}+C_{A}+C_{B}$

Now define $Q_{n+1}$ as a variable equal to +1 if trade $n+1$ started with a buy order and -1 if the trade started with a sell order. Also define $\varepsilon_{n+1}$ as the revision of the true price $\left(p_{n}\right)$ due to the arrival of new public information between trades $n$ and $n+1$. Therefore, the true price is

$$
p_{n+1}=p_{n}+\varepsilon_{n+1}+Z_{n+1} Q_{n+1}
$$

where $Z_{n+1}=Z_{A}$ if $Q_{n+1}=+1$ and $Z_{n+1}=Z_{B}$ if $Q_{n+1}=-1$. Note there are two innovations in the true price, one due to the public information and the other to the trade that happened. The price of the trade is

$$
\hat{p}_{\mathrm{n}+1}=p_{\mathrm{n}+1}+C Q_{\mathrm{n}+1},
$$

in which $C=C_{A}$ if $Q_{n+1}=+1$ and $C=C_{B}$ if $Q_{n+1}=-1$, with $C_{A}, C_{B}>0$. 
If we assume that $Z_{A}=Z_{B}$ and $C_{A}=C_{B}$, we have that $S=A-B=2(Z+C)$ or $\frac{s}{2}=Z+$ $C$. Besides this, $\mathrm{Z}$ is positive, since when there is a sale at $\mathrm{A}, \mathrm{E}\left[p^{*} \mid H\right.$, "investor buys at $\left.A^{\prime \prime}\right]$ is greater than $\mathrm{E}\left[p^{*} \mid H\right]$, i.e., $a(A)>p$ and $Z_{A}>0$.

Now assume that $Z$ and $C$ are constants, and let । and $\pi$ be proportions of $\frac{s}{2}$ due to $Z$ and $C$, respectively. Since $Z_{A}=Z_{B}$, । is also the proportion of the spread $(S)$ due to information asymmetry (2Z), and since $\mid=Z / \frac{s}{2}$, the true price (1) can be written as:

$$
p_{n+1}=p_{n}+\varepsilon_{n+1}+\alpha \frac{s}{2} Q_{n+1}
$$

and the trading price (2) for trade $n+1$ is

$$
\hat{p}_{\mathrm{n}+1}=p_{\mathrm{n}+1}+\pi \frac{s}{2} Q_{\mathrm{n}+1}
$$

Taking the first difference of (4), we obtain:

$$
\Delta \hat{p}_{\mathrm{n}+1}=\Delta p_{\mathrm{n}+1}+\pi \frac{s}{2} \Delta Q_{\mathrm{n}+1}
$$

Substituting $\Delta p n+1$ from (3) into (5), we have

$$
\begin{aligned}
& \Delta \hat{p}_{\mathrm{n}+1}=\varepsilon_{n+1}+\alpha \frac{s}{2} Q_{n+1}+\pi \frac{s}{2} \Delta Q_{\mathrm{n}+1} \\
& \Delta \hat{p}_{\mathrm{n}+1}=\varepsilon_{n+1}+\alpha \frac{s}{2} Q_{n+1}+(1-\alpha) \frac{s}{2} \Delta Q_{\mathrm{n}+1}
\end{aligned}
$$




$$
\Delta \widehat{\mathrm{p}}_{\mathrm{n}}=\varepsilon_{\mathrm{n}}+\alpha \frac{\mathrm{s}}{2} \mathrm{Q}_{\mathrm{n}-1}+\frac{\mathrm{s}}{2} \Delta \mathrm{Q}_{\mathrm{n}}
$$

Therefore, based on Equation (6), the coefficients of the information asymmetry $(\alpha)$ and the spread (s) are estimated.

The models in this section were estimated by the generalized method of moments (GMM), which imposes relaxed assumptions regarding the distributions. This is important because $\varepsilon_{\mathrm{n}}$ can have rounding errors (prices are discrete). The results of the estimations here are robust to various conditions of orthogonality, to the presence of serial autocorrelation and conditional heteroscedasticity. The information asymmetry coefficients are estimated daily (the values are in the appendix).

\section{HYPOTHESES AND RESULTS}

We carried out two hypothesis tests. The first was to verify whether the information asymmetry embedded in the bid-ask spread helps to explain the difference in returns between value and growth stock portfolios. The higher returns of value stocks should be explained by the risk premium paid because of the greater information asymmetry. For this test, we used the ratios between the returns and the asymmetry coefficients of the portfolios (return per unit of information asymmetry). If on average the ratios of the value and growth portfolios are different, we can affirm that it is not information asymmetry that causes the returns to be different.

Test 1: Alternative hypothesis $\left(\mathrm{H}_{1}\right)$ - There is a difference of the averages of the ratios of return and the degree of information asymmetry between value and growth portfolios.

The second test examines the hypothesis relating the daily volatility of the portfolios' returns with the degree of information asymmetry. More pronounced information asymmetry can mean less certainty regarding the future cash flows of the firm, increasing the volatility of its stock prices. However, firms with more volatile cash flows are not necessarily associated with greater information asymmetry. Firms with riskier cash flows, to soften this risk perception, can be more transparent to the point that the information asymmetry related to their stocks is small.

Test 2: Alternative hypothesis $\left(\mathrm{H}_{1}\right)$ - There is a correlation between information asymmetry and the volatilities of the daily returns of value and growth portfolios. 
Table 1 shows the period-by-period composition of the value and growth portfolios (as mentioned in Section 3, we rebalanced the portfolios on the dates of change of the Ibovespa). An important point to mention about the composition of the value portfolios is the consistent presence of the firms Eletrobrás, Copel, Sabesp and Celesc in all the periods. In the growth portfolio, only Souza Cruz was present in all the periods analyzed. It can also be noted in Table 1 that the BV/MV ratio of Eletrobrás is higher than the rest of the stocks in the value portfolio in all the periods.

Table 1: Value and growth portfolios by period, classified by BV/MV

\begin{tabular}{|c|c|c|c|}
\hline \multicolumn{4}{|c|}{ Portfolio 1, 06/30/06 to 08/31/06 } \\
\hline \multicolumn{2}{|c|}{ Vahue Novifoliso } & \multicolumn{2}{|c|}{ Cuavith sorcifolis } \\
\hline Stark & BXNAN & stask & REAT: \\
\hline metro & 2,36 & vatrs & 0.31 \\
\hline ETERS & 2,34 & Ancenva & 0,31 \\
\hline saspy & 1,55 & conss & 0.30 \\
\hline TRPLA & 1.15 & Babc 4 & 0,28 \\
\hline CPIEG & 100 & VALE3 & 0,27 \\
\hline Casce & 0,91 & THLivi & 0.36 \\
\hline BNTO4 & 0,00 & maxt4 & 0.34 \\
\hline nextra 4 & 0,84 & vasse 11 & $0.2 x$ \\
\hline PRERMS & 0.83 & CRUZZ3 & 0.16 \\
\hline InCirla & 0.00 & SIETCA & 0.13 \\
\hline
\end{tabular}

\begin{tabular}{|c|c|c|c|}
\hline \multicolumn{4}{|c|}{ Portfolio $2+0901 / 06+012 / 31 / 06$} \\
\hline \multicolumn{2}{|c|}{ Valuen Dartfolle } & \multicolumn{2}{|c|}{ Cirowih Toutrollo } \\
\hline Stank & RVANV & Starh & FEVAN \\
\hline zinto & 3,20 & vates & 0.35 \\
\hline FIET & 204 & roMESS & $0,3=$ \\
\hline SBSP3 & 1.36 & BADS4 & 0,32 \\
\hline TREPL 4 & 1,33 & AMOBVA & 0,31 \\
\hline BRTEA & 1.24 & Chass & 0.1 \\
\hline Buctids & 1,13 & ITAUA & 0.28 \\
\hline TManes & 1.09 & LCBABE 11 & D.an \\
\hline CMLE6 & 100 & clexuza & 0,18 \\
\hline Cusco & 0.95 & $C(R O)$ & 0.36 \\
\hline BQYKMTS & $0,8,2$ & NIETCA & 0,13 \\
\hline
\end{tabular}

\begin{tabular}{|c|c|c|c|}
\hline \multicolumn{4}{|c|}{ /30/07 } \\
\hline \multicolumn{2}{|c|}{ Value Yorifotio } & \multicolumn{2}{|c|}{ 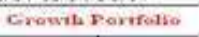 } \\
\hline stoch & BVAN & Steark & BVAr: \\
\hline mETe & 2.98 & HTAUa & 0,20 \\
\hline FIFTs & 2,71 & vales & 0.23 \\
\hline CESP6 & 125 & Ggass & 0.25 \\
\hline SRSP3 & 1.08 & URBRPII & 6.18 \\
\hline TMARS & 1.02 & NETSCA & 0,18 \\
\hline CDLFE & 0.03 & Tahimat & a.s \\
\hline Bxiro4 & 0.92 & cruzes & 0,14 \\
\hline casces & 0.91 & CCROS & 0.13 \\
\hline PRGAY & 0.83 & NATUR & 0.05 \\
\hline Tras 4 & O. & Arrun: & 0.04 \\
\hline
\end{tabular}

\begin{tabular}{|c|c|c|c|}
\hline \multicolumn{4}{|c|}{ Purffalian 41 06/02/07 to 08:31/07 } \\
\hline \multicolumn{2}{|c|}{ Ventue Partifulite } & \multicolumn{2}{|c|}{ Croweth Perefoblis } \\
\hline $5 \operatorname{tack}$ & BNAN & stask & By $201 \times$ \\
\hline मा1 & 3,02 & coners & 0.32 \\
\hline Fints & 3.01 & $\cos 14$ & 0.21 \\
\hline sBsirs & 1,20 & CSAMAS & 0.21 \\
\hline TMAKS & 1.14 & coass & 0.20 \\
\hline Crsspe. & 103 & $\cos a x+1 x$ & 0.12 \\
\hline cmiso & 1.00 & TAMMA & 0.16 \\
\hline asce & 0.00 & cruzza & 0.56 \\
\hline IIRKOMS & 0,96 & cerros & 0.11 \\
\hline TRPLA & 0.59 & МNTTU & 0.07 \\
\hline PREGAI & 0 & ALIIII & 0.03 \\
\hline
\end{tabular}

\begin{tabular}{|c|c|c|c|}
\hline \multicolumn{4}{|c|}{ Portfolito $610909 / 07$ in 12/28/07 } \\
\hline \multicolumn{2}{|c|}{ Vallen Pertifulia } & \multicolumn{2}{|c|}{ Crombli Partfolitim } \\
\hline stoes & BVANV & stecks & BNATY \\
\hline स्मात्र & 2,90 & VAXII & $0,2,2$ \\
\hline IIIII & 3,73 & TAMMU & Doge \\
\hline CIsco & 0.97 & Anmes & 0.20 \\
\hline CESP6 & 0.94 & CBASS & 0.12 \\
\hline SBSB: & -289 & GRLE: & 0.16 \\
\hline TMARS & o.n. & L.RTNI & 0.15 \\
\hline CPITo & 0.83 & CCROI & D.11 \\
\hline MRREMS & 0,77 & anTun & 0.00 \\
\hline PRGAN] & 0,08 & ntows & Deat \\
\hline Toups-4 & 0,63 & M11111 & Dot \\
\hline
\end{tabular}

\begin{tabular}{|c|c|c|c|}
\hline \multicolumn{4}{|c|}{ 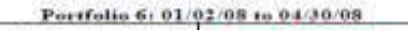 } \\
\hline \multicolumn{2}{|c|}{ Value Perrfotia } & \multicolumn{2}{|c|}{ Crowth Fentration } \\
\hline $\operatorname{sight}$ & BVAC: & stesch & BNATS \\
\hline गयाт & 3.04 & Asmy 4 & 0,32 \\
\hline 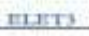 & 206 & varais & axo \\
\hline SAsPs & 1,02 & Cossuas & 0.18 \\
\hline CMLES & 0,98 & CCAROA & 0.14 \\
\hline casec6. & 0.91 & LEFAs & ods \\
\hline nukMMS & 0.00 & cauzs & 0.11 \\
\hline TMurs & D.85 & NATEU & 0,00 \\
\hline TAIPA & 0.80 & ntows & 0.04 \\
\hline procil & 0,73 & AI.1.1.11 & 0,04 \\
\hline CTSPB & 0.66 & ThaMtA & acas \\
\hline
\end{tabular}

\begin{tabular}{|c|c|c|c|}
\hline \multicolumn{4}{|c|}{ Pordolle th os opzos to 08:29.08 } \\
\hline \multicolumn{2}{|c|}{ Vinlan Portiotio } & \multicolumn{2}{|c|}{ Grewth Portrotes } \\
\hline Stack & BVANV & stock: & BV/AR \\
\hline mits & 2,07 & VATES & $0,0 x$ \\
\hline Earte & 3.54 & cansi & $0.1 \mathrm{n}$ \\
\hline BENCAS & 121 & congas & 0.17 \\
\hline Cespo & 1.20 & LKPIN 3 & 0.15 \\
\hline $\mathrm{SBSP}_{3}$ & 1,08 & CRUZ3 & 0,14 \\
\hline CPLEG & 1,00 & CCRO3 & 0.14 \\
\hline BRKMMS & 0.95 & NATUI & 0.09 \\
\hline asces & 0,05 & ntows & 0.04 \\
\hline Drocis & 0.51 & Atritit & 0.04 \\
\hline DNSP4 & 0.66 & WAMIE 4 & 0,03 \\
\hline
\end{tabular}

\begin{tabular}{|c|c|c|c|}
\hline \multicolumn{4}{|c|}{ Pertolite 81.090} \\
\hline \multicolumn{2}{|c|}{ Value Portfolto } & \multicolumn{2}{|c|}{ Growth Portolis } \\
\hline Stoek & BVArV & steek & BXNMY \\
\hline mints & 2.97 & Almiva & 0,24 \\
\hline mIXI & 2,31 & caAsa & D.23 \\
\hline snaps & 1.25 & CSNAT & 0.01 \\
\hline CESPS & 1,21 & LRENS & 0.19 \\
\hline CPLE6 & 1.03 & CRUZ3 & 0,24 \\
\hline BRKMIS & 1.00 & CCROO3 & 0.19 \\
\hline PROAA & 0.97 & NaTu2 & 0.10 \\
\hline Casco & 0,91 & Annitit & 0,05 \\
\hline TCSLA & 0,77 & miows & 0,04 \\
\hline BNACAR & 0,25 & IAMES 4 & bovi4 \\
\hline
\end{tabular}

\begin{tabular}{|c|c|c|c|}
\hline \multicolumn{4}{|c|}{ Pertfolice $2,01 / 90$} \\
\hline \multicolumn{2}{|c|}{ Velus Porifolio } & \multicolumn{2}{|c|}{ Growth Fortetise } \\
\hline stowh & BVArV & Steck & BVACN \\
\hline FIFT6 & 3.11 & nerps & 0.28 \\
\hline FIITI & 2.01 & TAAMMA & 0.23 \\
\hline REITI & 170 & SDIA & 0,17 \\
\hline CESPS & 1.62 & CCKO3 & 0,16 \\
\hline SBSP 3 & 1.50 & CRuZS & 0.16 \\
\hline BRKMMS & 1,32 & ALIIII & 0.09 \\
\hline PRGAS & 122 & NATUZ & 0.09 \\
\hline$C S=A S$ & 1,21 & stows & 0,01 \\
\hline CPLEB & 121 & Lanme-4 & 0.07 \\
\hline colse6 & 101 & Rascipes & 604 \\
\hline
\end{tabular}

\subsection{RETURNS AND VOLATILITY OF THE VALUE AND GROWTH PORTFOLIOS}

Figure 1 presents the evolution of the profitability of the value and growth portfolios in the period between July 2006 and April 2009. In this period, the cumulative profitability in nominal terms of the value portfolio was $53.47 \%$ and that of the growth portfolio was negative $29.80 \%$. Thus, Figure 1 indicates the superiority of the value portfolio compared to 
the growth portfolio in terms of return, as is usually observed in the literature. We performed difference of means tests for the sample of 698 returns of each portfolio. The parametric test of means with paired samples at $5 \%$ significance $(\mathrm{p}$-value $=1.88 \%)$ and the nonparametric Wilcoxon signed-rank test $(\mathrm{p}$-value $=1.68 \%$ ) confirmed the difference between the samples. The tests were performed with daily returns.

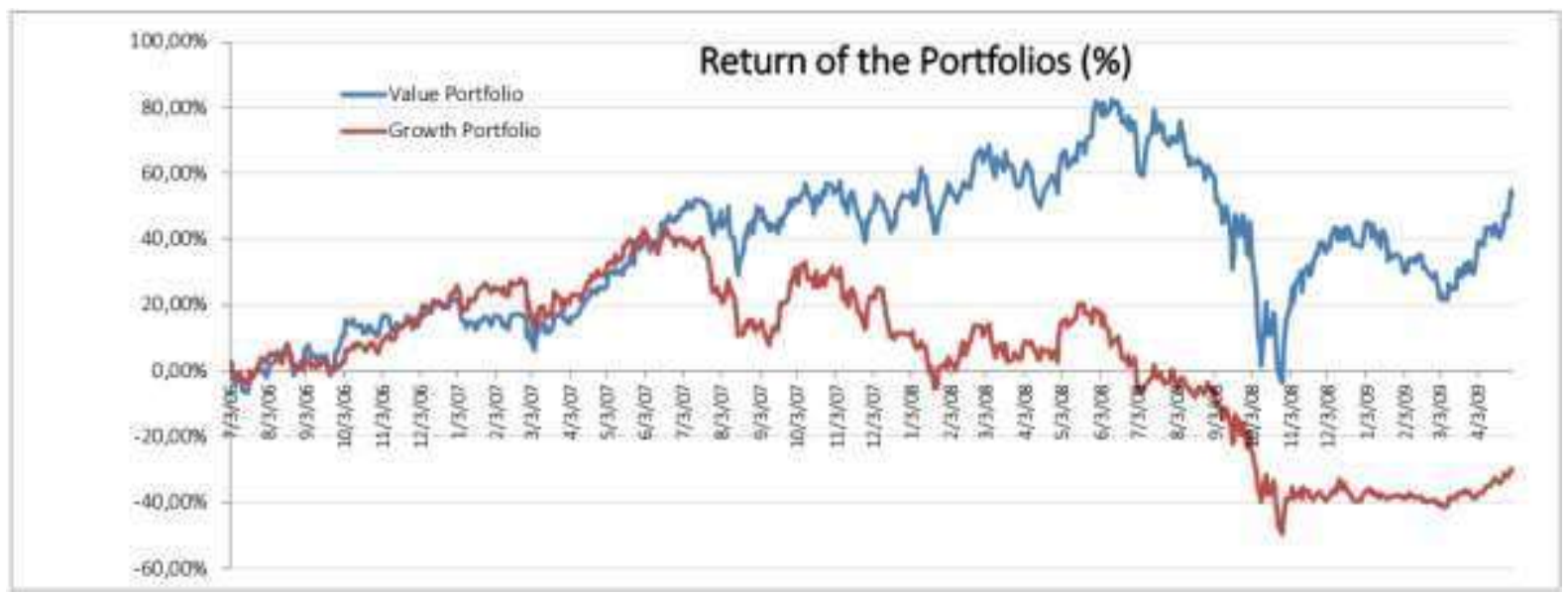

Figure 1: Evolution of the returns of the value and growth portfolios

In the period-by-period comparison of the nine four-month periods analyzed, the return of the growth portfolio exceeded that of the value portfolio in only three periods (Table 2). The volatilities of the portfolios over the entire period did not differ much: in the value portfolio, the annualized volatility is $33.02 \%$ and in the growth portfolio it is $33.70 \%$. $^{\mathrm{vi}}$ However, the same comparison by periods shows that the value portfolios are more stable than the growth portfolios in all the periods except the last four months of 2008, when they rose due to the subprime crisis. ${ }^{\text {vii }}$

Table 2: Return of the portfolios and volatility by periods

\begin{tabular}{|c|c|c|c|c|}
\hline \multirow{2}{*}{$\begin{array}{c}\text { Final Date of the } \\
\text { Portfolios }\end{array}$} & \multicolumn{2}{|c|}{ Value Portfolio } & \multicolumn{2}{c|}{ Growth Portfolio } \\
\cline { 2 - 5 } & Return & $\begin{array}{c}\text { Annualized } \\
\text { Volatility }\end{array}$ & Return & Annualized Volatility \\
\hline $08 / 31 / 2006$ & $3,18 \%$ & $27,23 \%$ & $0,37 \%$ & $25,88 \%$ \\
\hline $12 / 28 / 2006$ & $17,54 \%$ & $23,49 \%$ & $22,16 \%$ & $17,82 \%$ \\
\hline $04 / 30 / 2007$ & $3,00 \%$ & $23,42 \%$ & $5,15 \%$ & $24,99 \%$ \\
\hline $08 / 31 / 2007$ & $19,95 \%$ & $27,78 \%$ & $-12,27 \%$ & $23,33 \%$ \\
\hline $12 / 28 / 2007$ & $2,10 \%$ & $26,96 \%$ & $-3,96 \%$ & $33,07 \%$ \\
\hline $04 / 30 / 2008$ & $4,84 \%$ & $29,15 \%$ & $-0,30 \%$ & $38,02 \%$ \\
\hline $08 / 29 / 2008$ & $0,47 \%$ & $25,78 \%$ & $-10,60 \%$ & $27,53 \%$ \\
\hline $12 / 30 / 2008$ & $-14,53 \%$ & $62,23 \%$ & $-37,05 \%$ & $63,91 \%$ \\
\hline $04 / 30 / 2009$ & $11,44 \%$ & $30,25 \%$ & $13,83 \%$ & $20,29 \%$ \\
\hline Total Period & $\mathbf{5 3 , 4 7 \%}$ & $\mathbf{3 3 , 0 2 \%}$ & $\mathbf{- 2 9 , 8 0 \%}$ & $\mathbf{3 3 , 7 0 \%}$ \\
\hline
\end{tabular}

3.2 THE INFLUENCE OF INFORMATION ASYMMETRY ON THE VALUE AND GROWTH PORTFOLIOS 
Table 3 presents the information on the degree of asymmetry embedded in the bid-ask spread (in percent of the spread) and the ratio between the return and asymmetry level for each four-month period and the whole period. Although the table presents the data by periods, we ran the tests with daily data. To identify whether asymmetry influences the daily return of the portfolios, we performed tests of hypothesis 1 , analyzing the ratios between daily return asymmetry. The parametric test of means for paired samples at 5\% significance rejected the null hypothesis that the mean return/asymmetry ratio of the value portfolio was equal to the same ratio of the growth portfolio ( $\mathrm{p}$-value $=2.56 \%$ ). To check for robustness, we performed the nonparametric Wilcoxon signed-rank test, which also rejected the null hypothesis of equality ( $\mathrm{p}$-value $=1.67 \%$ ). Therefore, the tests indicate that, even after controlling for asymmetry, the portfolios' returns remain different.

Table 3: Relation between return of the portfolios and degree of Asymmetry between periods

\begin{tabular}{|c|c|c|c|c|}
\hline \multirow{2}{*}{$\begin{array}{c}\text { Final Date of the } \\
\text { Portfolios }\end{array}$} & \multicolumn{2}{|c|}{ Value } & \multicolumn{2}{c|}{ Growth } \\
\cline { 2 - 5 } & Degree of Asym. & Return/Asym. & Degree of Asym. & Return/Asym. \\
\hline $08 / 31 / 2006$ & $75,74 \%$ & $\mathbf{4 , 2 0 \%}$ & $71,62 \%$ & $\mathbf{0 , 5 2 \%}$ \\
\hline $12 / 28 / 2006$ & $75,21 \%$ & $\mathbf{2 3 , 3 2 \%}$ & $72,68 \%$ & $\mathbf{3 0 , 5 0 \%}$ \\
\hline $04 / 30 / 2007$ & $70,99 \%$ & $\mathbf{5 , 7 9 \%}$ & $71,57 \%$ & $\mathbf{7 , 1 9 \%}$ \\
\hline $08 / 31 / 2007$ & $72,54 \%$ & $\mathbf{2 7 , 8 4 \%}$ & $68,97 \%$ & $\mathbf{- 1 7 , 7 8 \%}$ \\
\hline $12 / 28 / 2007$ & $73,89 \%$ & $\mathbf{0 , 7 9 \%}$ & $63,70 \%$ & $\mathbf{- 6 , 2 2 \%}$ \\
\hline $04 / 30 / 2008$ & $71,91 \%$ & $\mathbf{9 , 1 2 \%}$ & $67,45 \%$ & $\mathbf{- 0 , 4 4 \%}$ \\
\hline $08 / 29 / 2008$ & $76,22 \%$ & $\mathbf{0 , 0 7 \%}$ & $77,77 \%$ & $\mathbf{- 1 3 , 6 3 \%}$ \\
\hline $12 / 30 / 2008$ & $83,37 \%$ & $\mathbf{- 1 5 , 1 9 \%}$ & $83,31 \%$ & $\mathbf{- 4 4 , 4 7 \%}$ \\
\hline $04 / 30 / 2009$ & $84,15 \%$ & $\mathbf{1 3 , 0 4 \%}$ & $84,46 \%$ & $\mathbf{1 6 , 3 8 \%}$ \\
\hline Total Period & $\mathbf{7 6 , 0 3 \%}$ & $\mathbf{6 8 , 9 8 \%}$ & $\mathbf{7 3 , 6 5 \%}$ & $\mathbf{- 2 7 , 9 5 \%}$ \\
\hline
\end{tabular}

The sample used in these tests could contain biases, given that the returns were not controlled for the usual risk premiums, such as the risk factors of Fama and French. Therefore, we repeated the test with the abnormal returns of the value and growth portfolios, defining abnormal return as actual return minus the expected return according to the model of Fama \& French $(1992,1993)$. The return in this model is defined in function of the SMB and HML factors, which respectively measure the additional return of the stocks of small versus big firms and between firms with high versus low book-to-market ratios, as well as the MRP, which measures the market risk premium of stocks. The factors were constructed monthly, according to the period of the sample. ${ }^{\text {vii }}$ However, in this study we did not use the HML factor, since using growth and value portfolios already controls for portfolios containing stocks with high and low book value in comparison with market value. 
The parametric test of means for paired samples did not reject the null hypothesis regarding the ratio of abnormal return and asymmetry between the value and growth stocks, at $5 \%$ significance $(\mathrm{p}$-value $=7.93 \%)$. The nonparametric Wilcoxon signed-rank test also did not reject the null hypothesis of equality $(\mathrm{p}$-value $=5.69 \%$ ). Hence, there are indications that asymmetry helps to explain the difference of returns between the portfolios.

The test of hypothesis 2 checks whether the volatility of the portfolios' returns is correlated with their information asymmetry. For this purpose, we ran two regressions - one for the value portfolio and the other for the growth portfolio. The dependent variable in both was the absolute value of the daily returns of the portfolios (as a proxy for volatility) and the independent variable was the degree of asymmetry of the portfolios. These regressions also had 698 observations. The results show there is a relation between the variables. As shown in Table 4 , the coefficient of the asymmetry variable is positive and significant at $1 \%$ for both portfolios. An increase in the information asymmetry coefficient has a stronger influence on the value than on the growth portfolio (i.e., the correlation between information asymmetry and volatility is greater for the value portfolio). This can suggest that the higher return of the value stocks is also explained by the greater sensitivity of the volatility of these stocks to the information received by their holders.

Table 4: Result of the regressions of the dependent variable square root of the daily returns against the asymmetry degree for the value and growth portfolios

\begin{tabular}{ccc}
\hline Information & $\begin{array}{c}\text { Coefficients } \\
\text { of the } \\
\text { Value } \\
\text { Portfolio }\end{array}$ & $\begin{array}{c}\text { Coefficients } \\
\text { of the } \\
\text { Growth } \\
\text { Portfolio }\end{array}$ \\
\hline $\begin{array}{c}\text { Intersection } \\
\text { Asymmetry } \\
\text { Variable }\end{array}$ & 0.00097 & 0.00341 \\
P-value & 0.018562 & 0.016016 \\
\hline
\end{tabular}

\section{CONCLUSIONS}

The objective of this study was to investigate whether the information asymmetry embedded in the bid-ask spread of value and growth stock portfolios helps explain the difference in the returns of these portfolios, as well as to verify if this asymmetry is correlated with the volatility of these returns.

The value and growth portfolios were constructed based on a procedure similar to that developed by Fama \& French (1992), using stocks making up the Ibovespa as a reference to form the portfolios. As a criterion for classification of the stocks composing the portfolios, we used the ratio between book value and market value, by which the value portfolios contained 
stocks of firms with higher book-to-market ratio and the growth portfolios those of firms with lower ratio. The information asymmetry component that forms the bid-ask spread was estimated according to the model of Huang \& Stoll (1997).

To investigate whether the information asymmetry component embedded in the bid-ask spread helps explain the difference in the returns of the value and growth portfolios, we created an index relating the abnormal return of each portfolio and information asymmetry. The results of comparing the portfolios' indexes suggest that the information asymmetry embedded in the bid-ask spread does help explain the higher returns of the value portfolio in relation to the growth portfolio. The results also suggest that the greater return of value stocks can be related to the greater sensitivity of the volatility of the returns of these stocks to information available to shareholders.

\section{REFERENCES}

AKERLOF, G. The market for "lemons": quality uncertainty and the market mechanism. The Quarterly Journal of Economics, v. 84, n. 3, p. 488-500, ago. 1970.

AMIHUD, Y.; MENDELSON, H. The effects of beta, bid-ask spread, residual risk, and size on stock returns. Journal of Finance, v. 44, n. 2, p. 479-486, jun. 1989.

ARAÚJO, G. S.; BARBEDO, C. H. S.; VICENTE, J. V. M. The adverse selection cost component of the spread of Brazilian stocks. Central Bank of Brazil, Research

Department, Working Papers Series 263, 2011.

BASU, S. Investment performance of common stocks in relation to their price-earnings ratios. Journal of Finance, v. 32, n. 3, p. 663-682, 1977.

CHAN, Louis K. C.; JEGADEESH, Narasimhan; LAKONISHOK, Josef. Evaluating the performance of value versus glamour stocks: the impact of selection bias. Journal of Financial Economics, v. 38, n. 3, p. 269-296, 1995.

COSTA JR., Newton C. A.; NEVES, Myrian B. E. Variáveis fundamentalistas e retornos das ações. In: COSTA JR., Newton C. A.; LEAL, Ricardo P. C.; LEMBRUGER, Eduardo F. (Org.). Mercado de capitais: análise empírica no Brasil. São Paulo: Atlas, 2000. p. 100-111.

FAMA, Eugene F.; FRENCH, Kenneth R. The cross-section of expected stock returns. Journal of Finance, v. 47, n. 2, p. 427-465, jun. 1992.

FAMA, Eugene F.; FRENCH K. R. Common risk factors in the returns on stocks and bonds. Journal of Financial Economics, v. 33, n. 1, p. 3-56, 1993.

FAMA, Eugene F.; FRENCH, Kenneth R. Value versus growth: the international evidence. Journal of Finance, v. 53, n. 6, p. 1975-1999, dez. 1998.

GLOSTEN, L. R. Components of the bid-ask spread and the statistical properties of transaction prices. Journal of Finance, v. 42, n. 5, p. 1293-1307, 1987. 
GLOSTEN, L. R.; HARRIS, L. E. Estimating the components of the bid-ask spread. Journal of Financial Economics, v. 21, n. 1, p. 123-142, 1988.

GULEN, H.; XING, Y.; ZHANG, L. Value versus growth: time-varying expected stock returns. Financial Management, v. 40, n. 2, p. 381-407, 2011.

HAUGEN, Robert A. The new finance: the case against efficient markets. Englewood Cliffs: Prentice Hall, 1995.

HAUGEN, R.; BAKER, N. L. Commonality in the determinants of expected stock returns. Journal of Financial Economics, v. 41, n. 3, p. 401-439, 1996.

HAZZAN, S. Desempenho de ações da bolsa de valores de São Paulo e sua relação com o índice preço-lucro. 1991. 263 f. Tese (Doutorado em Administração) - Curso de PósGraduação da Escola de Administração de Empresas de São Paulo, Fundação Getúlio Vargas, São Paulo, 1991.

HOLLOWAY, P. A filosofia value investing na gestão de fundos de investimentos brasileiros. 2012. 64 f. Dissertação (Mestrado em Finanças e Economia de Empresas) Escola de Economia de São Paulo, Fundação Getúlio Vargas, São Paulo, 2012.

HUANG, R. D.; STOLL, H. R. The components of the bid-ask spread: a general approach. Review of Financial Studies, v. 10, n. 4, p. 995-1034, 1997.

LAKONISHOK, J.; SHLEIFER, A.; VISHNY, R. W. Contrarian investment, extrapolation, and risk. Journal of Finance, v. 49, n. 5, p. 1541-1578, dez. 1994.

LOPES, Alexsandro B.; GALDI, Fernando C. Does financial statement analysis generate abnormal returns under extremely adverse conditions? In: ENCONTRO BRASILEIRO DE FINANÇAS, 7., 2007, São Paulo. Anais... São Paulo: IBMEC, 2007.

LUCENA, P. et al. Testando o "mito de investimento": é uma boa estratégia investir em ações de baixo índice P/L no Brasil? In: ENCONTRO BRASILEIRO DE FINANÇAS, 8., 2008, Rio de Janeiro. Anais... Rio de Janeiro: IBMEC, 2008.

NAGANO, Marcelo S.; MERLO, Edgard M.; SILVA, Maristela C. As variáveis fundamentalistas e seus impactos na taxa de retorno de ações no Brasil. Revista da FAE, Curitiba, v. 6, n. 2, p. 13-28, maio/dez. 2003.

RAMOS, Patrícia B.; PICANÇO, Marcelo B.; COSTA JR., Newton C. A. Retornos e riscos das value e growth stocks no mercado brasileiro. In: COSTA JR., Newton C. A.; LEAL, Ricardo P. C.; LEMBRUGER, Eduardo F. (Org.). Mercado de capitais: análise empírica no Brasil. São Paulo: Atlas, 2000. p. 124-138.

ROLL, R. A simple implicit measure of the effective bid-ask spread in an efficient market. Journal of Finance, v. 39, n. 4, p. 1127-1139, 1984.

ROSTAGNO, L., SOARES, R., SOARES, K. Value strategies in the Brazilian stock market. In: CONFERENCE BUSINESS ASSOCIATION OF LATIN AMERICAN STUDIES (BALAS). Proceedings... São Paulo: 2003. 
SHARPE, W. F.; CAPAUL, C.; ROWLEY, I. International value and growth stock returns. Financial Analysts Journal, v. 49, n. 1, p. 27-36, 1993.

STOLL, H. R. The supply of dealer services in securities markets. Journal of Finance, v. 33, n. 4, p. 1133-1151, 1978.

STOLL, H. R. Inferring the components of the bid-ask spread: theory and empirical tests. Journal of Finance, v. 44, n. 1, p. 115-134, 1989.

YU, J. Disagreement and return predictability of stock portfolios. Journal of Financial Economics, v. 99, n. 1, p. 162-183, 2011. 


\section{APPENDIX - AVERAGE VALUE OF ASYMMETRY AS A PERCENTAGE OF THE BID-ASK SPREAD (DEGREE OF ASYMMETRY) OF EACH PORTFOLIO}

\begin{tabular}{|c|c|c|}
\hline \multicolumn{3}{|c|}{ Dortrotin 1} \\
\hline Date & Value & Growth \\
\hline $03 / 07 / 2006$ & $76,70 \%$ & $68,72 \%$ \\
\hline $04 / 0712006$ & $74.23 \%$ & $71,58 \%$ \\
\hline $06107 / 2006$ & $73,73 \%$ & $62,06 \%$ \\
\hline 0610712006 & $70.46 \%$ & $70,10 \%$ \\
\hline $07 / 07 / 2006$ & $62,08 \%$ & $66,37 \%$ \\
\hline $1007 / 2006$ & $64,54 \%$ & $76,25 \%$ \\
\hline $11 / 07 / 2006$ & $82.93 \%$ & $65,94 \%$ \\
\hline $12107 / 2006$ & $73.81 \%$ & $66.30 \%$ \\
\hline $13 / 07 / 2006$ & $73,91 \%$ & $72,32 \%$ \\
\hline $14 / 07 / 2006$ & $85,58 \%$ & $67,17 \%$ \\
\hline $17 / 0712006$ & $83,13 \%$ & $66.87 \%$ \\
\hline $18 / 07 / 2006$ & $89,65 \%$ & $70,93 \%$ \\
\hline $1907 / 2006$ & $82,47 \%$ & $76.81 \%$ \\
\hline 2000712006 & $75.81 \%$ & $65,93 \%$ \\
\hline $21 / 07 / 2006$ & $75,46 \%$ & $76.56 \%$ \\
\hline $24 / 07 / 2006$ & $63,46 \%$ & $63,54 \%$ \\
\hline 2510712006 & $74,12 \%$ & $57,09 \%$ \\
\hline 2610712006 & $74,02 \%$ & $72,33 \%$ \\
\hline $27 / 07 / 2006$ & $75.27 \%$ & $66,70 \%$ \\
\hline $2807 / 2006$ & $70,82 \%$ & $63,39 \%$ \\
\hline $31 / 07 / 2006$ & $64,64 \%$ & $68.17 \%$ \\
\hline $01 / 08 / 2006$ & $71,28 \%$ & $72,55 \%$ \\
\hline 020012006 & $75,56 \%$ & $71,99 \%$ \\
\hline $02 y 002006$ & $65,56 \%$ & $61,96 \%$ \\
\hline $04 / 08 / 2006$ & $85,08 \%$ & $73.15 \%$ \\
\hline $07 / 10082006$ & $70,18 \%$ & $81,04 \%$ \\
\hline $0 E 0012006$ & $74,15 \%$ & $75,70 \%$ \\
\hline $00 \% 08 / 2006$ & $75,87 \%$ & $81,54 \%$ \\
\hline $10 / 08 / 2006$ & $74,43 \%$ & $75,22 \%$ \\
\hline $11 / 0012006$ & $76.77 \%$ & $70.91 \%$ \\
\hline $14 / 08 / 2006$ & $71.71 \%$ & $75,92 \%$ \\
\hline $15 / 08 / 2006$ & $81,04 \%$ & $73,94 \%$ \\
\hline $1606 / 2006$ & $74,39 \%$ & $74.98 \%$ \\
\hline $17 / 08 / 2006$ & $76.07 \%$ & $81,66 \%$ \\
\hline $18 / 022006$ & $83,59 \%$ & $72,60 \%$ \\
\hline $21 / 08 / 2006$ & $77,63 \%$ & $67,56 \%$ \\
\hline 2210812006 & $74,45 \%$ & $78.75 \%$ \\
\hline 230812006 & $79,78 \%$ & $63.08 \%$ \\
\hline $24 / 00 / 2006$ & $72.28 \%$ & $79,42 \%$ \\
\hline $2508 / 2006$ & $80.07 \%$ & $82.86 \%$ \\
\hline $28108 / 2006$ & $76.07 \%$ & $67,59 \%$ \\
\hline $2900 / 2006$ & $82,01 \%$ & $82,01 \%$ \\
\hline $30 \mathrm{\gamma} 0 \mathrm{e} / 2006$ & $91,73 \%$ & $76,72 \%$ \\
\hline $31 / 08 / 2006$ & $75.82 \%$ & $77.78 \%$ \\
\hline
\end{tabular}

\begin{tabular}{|c|c|c|}
\hline \multicolumn{3}{|c|}{ porttolto 2} \\
\hline Date & Value & Growth \\
\hline $01 / 09 / 2006$ & $71,49 \%$ & $68,81 \%$ \\
\hline $04 / 00 / 2006$ & $73,92 \%$ & $68,18 \%$ \\
\hline $05 / 092006$ & $74,84 \%$ & $72,42 \%$ \\
\hline $06 / 09 / 2006$ & $69,01 \%$ & $61,57 \%$ \\
\hline
\end{tabular}

\begin{tabular}{|l|c|c|}
\hline \multicolumn{3}{|c|}{ Prortfolio a 3} \\
\hline Date & Value & Growth \\
\hline $02 / 01 / 2007$ & $63,43 \%$ & $63,29 \%$ \\
\hline $03101 / 2007$ & $74,02 \%$ & $66,98 \%$ \\
\hline
\end{tabular}

\begin{tabular}{|l|l|l|}
\hline $06 / 092006$ & $69,01 \%$ & $61,57 \%$ \\
\hline
\end{tabular}

\begin{tabular}{|l|l|l|}
\hline $08 / 00 / 2006$ & $58,33 \%$ & $54,44 \%$ \\
\hline $11 / 00 / 2006$ & $70,44 \%$ & $52,39 \%$ \\
\hline
\end{tabular}

\begin{tabular}{|l|l|l|}
\hline $12 / 022006$ & $74,94 \%$ & $64,98 \%$ \\
\hline $13 / 0 \% 2006$ & $73,12 \%$ & $50,33 \%$ \\
\hline
\end{tabular}

\begin{tabular}{|l|l|l|}
\hline $13 / 092006$ & $73,12 \%$ & $50,33 \%$ \\
\hline $14 / 092006$ & $77,93 \%$ & $68,40 \%$ \\
\hline
\end{tabular}

\begin{tabular}{|l|l|l|}
\hline $15 / 092006$ & $77,93 \%$ & $68,40 \%$ \\
\hline $15 / 092006$ & $80,46 \%$ & $70,18 \%$ \\
\hline
\end{tabular}

\begin{tabular}{|l|l|l|}
\hline $18 / 0922006$ & $50,78 \%$ & $69,23 \%$ \\
\hline $19 / 09 \% 2006$ & $03,73 \%$ & $79,48 \%$ \\
\hline
\end{tabular}

\begin{tabular}{|l|l|l|}
\hline $19 / 09 / 2006$ & $63,73 \%$ & $79,46 \%$ \\
\hline $20 / 09 / 2006$ & $76,11 \%$ & $81,28 \%$ \\
\hline
\end{tabular}

\begin{tabular}{|l|l|l|}
\hline $21 / 092006$ & $74,98 \%$ & $73,86 \%$ \\
\hline
\end{tabular}

\begin{tabular}{|l|l|l|}
\hline $22 / 082006$ & $60,28 \%$ & $80,30 \%$ \\
\hline
\end{tabular}

\begin{tabular}{|l|l|l|}
\hline $25 / 092006$ & $65,12 \%$ & $64,43 \%$ \\
\hline
\end{tabular}

\begin{tabular}{|l|l|l|}
\hline $26 / 092006$ & $69,38 \%$ & $74,90 \%$ \\
\hline $27 / 0922006$ & $78,99 \%$ & $81,08 \%$ \\
\hline
\end{tabular}

\begin{tabular}{|l|l|l|}
\hline $28 / 09 / 2006$ & $69,32 \%$ & $67,56 \%$ \\
\hline
\end{tabular}

\begin{tabular}{|l|l|l|}
\hline $29 / 09 / 2006$ & $71,46 \%$ & $71,75 \%$ \\
\hline $02 / 10 / 2006$ & $73,44 \%$ & $80,70 \%$ \\
\hline
\end{tabular}

\begin{tabular}{|l|l|l|}
\hline $02 / 10 / 2006$ & $73,44 \%$ & $80,70 \%$ \\
\hline $03 / 10 / 2006$ & $78,64 \%$ & $76.52 \%$ \\
\hline
\end{tabular}

\begin{tabular}{|l|l|l|}
\hline $03 / 10 / 2006$ & $78,64 \%$ & $76,52 \%$ \\
\hline $04 / 102006$ & $83,22 \%$ & $83,65 \%$ \\
\hline
\end{tabular}

\begin{tabular}{|l|l|l|}
\hline 051102006 & $82,25 \%$ & $72,99 \%$ \\
\hline
\end{tabular}

\begin{tabular}{|l|l|l|}
\hline $06 / 10 / 2006$ & $74,97 \%$ & $84,71 \%$ \\
\hline
\end{tabular}

\begin{tabular}{|l|c|c|}
\hline $09 / 102006$ & $70,56 \%$ & $76,97 \%$ \\
\hline $10 / 102006$ & $78,11 \%$ & $70,58 \%$ \\
\hline $1 / 102006$ & $83,71 \%$ & $68,81 \%$ \\
\hline
\end{tabular}

\begin{tabular}{|l|c|c|}
\hline $10 / 102006$ & $78,11 \%$ & $70,58 \%$ \\
\hline $11 / 1022006$ & $83,71 \%$ & $68,81 \%$ \\
\hline
\end{tabular}

\begin{tabular}{|l|l|l|}
\hline $11 / 10 / 2006$ & $83,71 \%$ & $68,81 \%$ \\
\hline $13 / 10 / 2006$ & $79,62 \%$ & $71,54 \%$ \\
\hline
\end{tabular}

\begin{tabular}{|l|c|c|}
\hline $16 / 102006$ & $76,16 \%$ & $81,81 \%$ \\
\hline $17 / 10 \% 2006$ & $78,62 \%$ & $78,60 \%$ \\
\hline
\end{tabular}

\begin{tabular}{|l|l|l|}
\hline $18 / 10 / 2006$ & $63,80 \%$ & $57,86 \%$ \\
\hline
\end{tabular}

\begin{tabular}{|l|l|l|}
\hline $19 / 102006$ & $87,85 \%$ & $83,22 \%$ \\
\hline
\end{tabular}

\begin{tabular}{|l|l|l|}
\hline $20 / 102006$ & $82,48 \%$ & $94,19 \%$ \\
\hline $22 / 102006$ & $72,32 \%$ & $81,00 \%$ \\
\hline
\end{tabular}

\begin{tabular}{|l|l|l|}
\hline $23 / 10 / 2006$ & $72,32 \%$ & $81,00 \%$ \\
\hline $24 / 10 / 2006$ & $81,06 \%$ & $66,58 \%$ \\
\hline
\end{tabular}

\begin{tabular}{|l|l|l|}
\hline $25 / 102006$ & $75,18 \%$ & $69,79 \%$ \\
\hline
\end{tabular}

\begin{tabular}{|l|l|l|}
\hline $76 / 102006$ & $74,24 \%$ & $78,66 \%$ \\
\hline
\end{tabular}

\begin{tabular}{|l|l|l|}
\hline $27 / 10 / 2006$ & $66,41 \%$ & $83,10 \%$ \\
\hline
\end{tabular}

\begin{tabular}{|l|l|l|}
\hline $30 / 102006$ & $80,49 \%$ & $79,66 \%$ \\
\hline $31 / 102006$ & $78,83 \%$ & $66,99 \%$ \\
\hline
\end{tabular}

\begin{tabular}{|l|l|l|}
\hline $01 / 11 / 2006$ & $76,96 \%$ & $78,68 \%$ \\
\hline
\end{tabular}

\begin{tabular}{|c|c|c|}
\hline $03 / 11 / 2006$ & $78,68 \%$ & $65,75 \%$ \\
\hline $06 / 11 / 2006$ & $72, \%$ & $71,0 \%$ \\
\hline
\end{tabular}

\begin{tabular}{|l|l|l|}
\hline $06 / 11 / 2006$ & $72,89 \%$ & $71,01 \%$ \\
\hline
\end{tabular}

\begin{tabular}{|l|l|l|}
\hline $07 / 11 / 2006$ & $80,05 \%$ & $62,98 \%$ \\
\hline $09 / 11 / 2006$ & $83,66 \%$ & $75,01 \%$ \\
\hline
\end{tabular}

\begin{tabular}{|l|l|l|}
\hline $0 \mathrm{O} / 11 / 2006$ & $83,66 \%$ & $75,01 \%$ \\
\hline $09 / 11 / 2006$ & $69,15 \%$ & $68,88 \%$ \\
\hline $10 / 11 / 2006$ & $83,31 \%$ & $72,31 \%$ \\
\hline
\end{tabular}

\begin{tabular}{|l|l|l|}
\hline $10 / 11 / 2006$ & $83,34 \%$ & $72,31 \%$ \\
\hline
\end{tabular}

\begin{tabular}{|c|c|c|}
\hline $13 / 11 / 2006$ & $87,66 \%$ & $83,79 \%$ \\
\hline $14 / 11 / 2006$ & $79,87 \%$ & $77,16 \%$ \\
\hline
\end{tabular}

\begin{tabular}{|l|l|l|}
\hline $14 / 11 / 2006$ & $79,87 \%$ & $77,16 \%$ \\
\hline $16 / 11 / 2006$ & $82,03 \%$ & $72,56 \%$ \\
\hline
\end{tabular}

\begin{tabular}{|l|l|l|}
\hline $16 / 11 / 2006$ & $82,03 \%$ & $72,56 \%$ \\
\hline $17 / 11 / 2006$ & $87,49 \%$ & $66,35 \%$ \\
\hline
\end{tabular}

\begin{tabular}{|l|c|c|}
\hline $21 / 11 / 2006$ & $81,40 \%$ & $67,49 \%$ \\
\hline $2211 / 2006$ & $75,06 \%$ & $84,90 \%$ \\
\hline
\end{tabular}

\begin{tabular}{|l|l|l|}
\hline $22 / 11 / 2006$ & $75,05 \%$ & $64,90 \%$ \\
\hline $23 / 11 / 2006$ & $78,51 \%$ & $55,71 \%$ \\
\hline
\end{tabular}

\begin{tabular}{|l|l|l|}
\hline $23 / 11 / 2006$ & $78.51 \%$ & $55,71 \%$ \\
\hline $24 / 11 / 2006$ & $75,60 \%$ & $76,10 \%$ \\
\hline
\end{tabular}

\begin{tabular}{|l|l|l|}
\hline $24 / 11 / 2006$ & $75,60 \%$ & $76,10 \%$ \\
\hline $27111 / 2006$ & $85,57 \%$ & $87,49 \%$ \\
\hline
\end{tabular}

\begin{tabular}{|l|l|l|}
\hline $28 / 11 / 2006$ & $88,90 \%$ & $82,94 \%$ \\
\hline $29 / 11 / 2006$ & $7223 \%$ & $77,50 \%$ \\
\hline
\end{tabular}

\begin{tabular}{|l|l|l|}
\hline $29 / 11 / 2006$ & $72,23 \%$ & $77,50 \%$ \\
\hline
\end{tabular}

\begin{tabular}{|l|l|l}
\hline $30 / 11 / 2006$ & $80,71 \%$ & $75,14 \%$ \\
\hline
\end{tabular}

\begin{tabular}{|l|c|c|}
\hline $01 / 12 / 2006$ & $88,26 \%$ & $80,45 \%$ \\
\hline $04 / 12 / 2006$ & $86,86 \%$ & $73,22 \%$ \\
\hline
\end{tabular}

\begin{tabular}{|l|l|l|}
\hline $04 / 12 / 2006$ & $86,86 \%$ & $73,22 \%$ \\
\hline $05 / 12 / 2006$ & $84,35 \%$ & $82,41 \%$ \\
\hline
\end{tabular}

\begin{tabular}{|l|l|l|}
\hline $05 / 12 / 2006$ & $84,35 \%$ & $82,41 \%$ \\
\hline $06 / 12 / 2006$ & $74,35 \%$ & $71,43 \%$ \\
\hline
\end{tabular}

\begin{tabular}{|l|l|l|}
\hline $07 / 12 / 2006$ & $70,30 \%$ & $70,62 \%$ \\
\hline
\end{tabular}

\begin{tabular}{|l|l|l|}
\hline $08 / 12 / 2006$ & $77,92 \%$ & $88,96 \%$ \\
\hline $11 / 122006$
\end{tabular}

\begin{tabular}{|l|l|l|}
\hline $11 / 12 / 2006$ & $72,39 \%$ & $79,92 \%$ \\
\hline $12 / 12 / 2006$ & $75,90 \%$ & $77,69 \%$ \\
\hline
\end{tabular}

\begin{tabular}{|l|l|l|}
\hline $12 / 12 / 2006$ & $75,90 \%$ & $77,69 \%$ \\
\hline $13 / 12 / 2006$ & $45,97 \%$ & $46,02 \%$ \\
\hline
\end{tabular}

\begin{tabular}{|l|c|c|}
\hline $14 / 12 / 2006$ & $81,43 \%$ & $76,29 \%$ \\
\hline $15 / 12 / 2006$ & $73,96 \%$ & $67,51 \%$ \\
\hline
\end{tabular}

\begin{tabular}{|l|l|l|}
\hline $15 / 12 / 2006$ & $73,90 \%$ & $67,54 \%$ \\
\hline $19 / 12 / 2006$ & $72,50 \%$ & $60,49 \%$ \\
\hline
\end{tabular}

\begin{tabular}{|l|l|l|}
\hline $18 / 12 / 2006$ & $72,50 \%$ & $60,43 \%$ \\
\hline $19 / 12 / 2006$ & $74,85 \%$ & $84,37 \%$ \\
\hline
\end{tabular}

\begin{tabular}{|l|l|l|}
\hline $19 / 12 / 2006$ & $74,85 \%$ & $84,37 \%$ \\
\hline $20 / 12 / 2006$ & $78,20 \%$ & $71,56 \%$ \\
\hline
\end{tabular}

\begin{tabular}{|l|l|l|}
\hline $21 / 12 / 2006$ & $82,98 \%$ & $83,16 \%$ \\
\hline
\end{tabular}

\begin{tabular}{|l|l|l|}
\hline $22 / 12 / 2006$ & $66,97 \%$ & $70,66 \%$ \\
\hline
\end{tabular}

\begin{tabular}{|l|l|l}
\hline $26112 / 2006$ & $51,43 \%$ & $50,42 \%$ \\
\hline
\end{tabular}

\begin{tabular}{|l|l|l}
$27 / 12 / 2006$ & $71,59 \%$ & $69,77 \%$ \\
\hline
\end{tabular}

\begin{tabular}{|l|l|l|}
\hline $28 / 12 / 2006$ & $65,10 \%$ & $62,74 \%$ \\
\hline
\end{tabular} 


\begin{tabular}{|c|c|c|}
\hline \multicolumn{3}{|c|}{ Portfolio 4} \\
\hline Date & Value & Growth \\
\hline @/ 052007 & $61,92 \%$ & $57,26 \%$ \\
\hline @/ $05 / 2007$ & $70,37 \%$ & $62,86 \%$ \\
\hline $04 / 052007$ & $68,49 \%$ & $74,51 \%$ \\
\hline $07 / 05 / 2007$ & $74,11 \%$ & $63,06 \%$ \\
\hline $08 / 05 / 2007$ & $62,79 \%$ & $60,52 \%$ \\
\hline $09 / 05 / 2007$ & $71,48 \%$ & $71,43 \%$ \\
\hline $10 / 052007$ & $61,41 \%$ & $79,04 \%$ \\
\hline $11 / 05 / 2007$ & $73,98 \%$ & $71,69 \%$ \\
\hline $14 / 05 / 2007$ & $70,74 \%$ & $68,85 \%$ \\
\hline $15 / 05 / 2007$ & $74,54 \%$ & $72,65 \%$ \\
\hline $16 / 05 / 2007$ & $68,33 \%$ & $64,04 \%$ \\
\hline $17 / 052007$ & $57,90 \%$ & $71,48 \%$ \\
\hline $18 / 05 / 2007$ & $60,34 \%$ & $53,15 \%$ \\
\hline $21 / 05 / 2007$ & $82,19 \%$ & $81,66 \%$ \\
\hline $22 / 052007$ & $66,87 \%$ & $78,14 \%$ \\
\hline $23 / 05 / 2007$ & $72,70 \%$ & $67,71 \%$ \\
\hline $24 / 05 / 2007$ & $76,57 \%$ & $76,11 \%$ \\
\hline $25 / 05 / 2007$ & $66,90 \%$ & $68,28 \%$ \\
\hline $28 / 052007$ & $56,20 \%$ & $66,57 \%$ \\
\hline $29 / 052007$ & $65,93 \%$ & $76,71 \%$ \\
\hline $30 / 05 / 2007$ & $67,94 \%$ & $60,87 \%$ \\
\hline $31 / 052007$ & $65,74 \%$ & $60,58 \%$ \\
\hline $01 / 062007$ & $68,05 \%$ & $64,26 \%$ \\
\hline $04 / 062007$ & $74,02 \%$ & $69,10 \%$ \\
\hline $06 / 062007$ & $74,37 \%$ & $77,71 \%$ \\
\hline $06 / 062007$ & $76,83 \%$ & $66,60 \%$ \\
\hline$@ / 062007$ & $81,83 \%$ & $65,21 \%$ \\
\hline $11 / 062007$ & $76,55 \%$ & $73,84 \%$ \\
\hline $12 / 062007$ & $80,24 \%$ & $70,83 \%$ \\
\hline $13 / 062007$ & $86,27 \%$ & $91,12 \%$ \\
\hline $14 / 062007$ & $61,67 \%$ & $62,01 \%$ \\
\hline $15 / 062007$ & $64,37 \%$ & $61,71 \%$ \\
\hline $18 / 062007$ & $69,39 \%$ & $60,66 \%$ \\
\hline $19 / 062007$ & $62,78 \%$ & $51,81 \%$ \\
\hline $20 / 062007$ & $67,73 \%$ & $62,57 \%$ \\
\hline $21 / 062007$ & $76,73 \%$ & $71,38 \%$ \\
\hline 221062007 & $90,85 \%$ & $66,10 \%$ \\
\hline $25 / 062007$ & $79,23 \%$ & $73,51 \%$ \\
\hline $26 / 062007$ & $77,22 \%$ & $65,86 \%$ \\
\hline $27 / 062007$ & $76,28 \%$ & $70,34 \%$ \\
\hline $28 / 062007$ & $71,72 \%$ & $70,04 \%$ \\
\hline $29 / 062007$ & $79,97 \%$ & $62,26 \%$ \\
\hline @/ $07 / 2007$ & $75,57 \%$ & $71,78 \%$ \\
\hline$@ / 07 / 2007$ & $82,78 \%$ & $75,31 \%$ \\
\hline $04 / 07 / 2007$ & $74,33 \%$ & $58,86 \%$ \\
\hline $06 / 07 / 2007$ & $75,78 \%$ & $79,17 \%$ \\
\hline $06 / 07 / 2007$ & $71,31 \%$ & $66,28 \%$ \\
\hline $10 / 07 / 2007$ & $73,01 \%$ & $68,26 \%$ \\
\hline $11 / 07 / 2007$ & $82,27 \%$ & $73,07 \%$ \\
\hline $12 / 07 / 2007$ & $75,49 \%$ & $63,50 \%$ \\
\hline $13 / 07 / 2007$ & $72,74 \%$ & $58,12 \%$ \\
\hline $16 / 07 / 2007$ & $65,79 \%$ & $62,57 \%$ \\
\hline $17 / 07 / 2007$ & $70,27 \%$ & $57,55 \%$ \\
\hline $18 / 07 / 2007$ & $54,53 \%$ & $62,72 \%$ \\
\hline $19 / 07 / 2007$ & $71,76 \%$ & $52,82 \%$ \\
\hline $20 / 07 / 2007$ & $69,71 \%$ & $56,07 \%$ \\
\hline $23 / 07 / 2007$ & $68,61 \%$ & $66,72 \%$ \\
\hline $24 / 07 / 2007$ & $81,23 \%$ & $58,31 \%$ \\
\hline $25 / 07 / 2007$ & $73,76 \%$ & $74,26 \%$ \\
\hline $26 / 07 / 2007$ & $86,39 \%$ & $62,38 \%$ \\
\hline $27 / 07 / 2007$ & $78,01 \%$ & $70,27 \%$ \\
\hline $30 / 07 / 2007$ & $77,94 \%$ & $83,91 \%$ \\
\hline $31 / 07 / 2007$ & $76,33 \%$ & $76,25 \%$ \\
\hline $01 / 082007$ & $76,36 \%$ & $75,63 \%$ \\
\hline Q/ 082007 & $75,34 \%$ & $76,22 \%$ \\
\hline $03 / 082007$ & $71,87 \%$ & $69,26 \%$ \\
\hline $06 / 082007$ & $82,87 \%$ & $74,38 \%$ \\
\hline $07 / 082007$ & $77,30 \%$ & $82,62 \%$ \\
\hline $08 / 08 / 2007$ & $76,82 \%$ & $70,01 \%$ \\
\hline $08 / 082007$ & $82,64 \%$ & $73,05 \%$ \\
\hline $10 / 082007$ & $74,67 \%$ & $76,13 \%$ \\
\hline $13 / 082007$ & $85,24 \%$ & $76,97 \%$ \\
\hline $14 / 082007$ & $83,83 \%$ & $70,08 \%$ \\
\hline $15 / 08$ 2007 & $62,04 \%$ & $65,12 \%$ \\
\hline $16 / 082007$ & $66,29 \%$ & $77,05 \%$ \\
\hline $17 / 082007$ & $68,05 \%$ & $78,87 \%$ \\
\hline $20 / 082007$ & $79,88 \%$ & $67,49 \%$ \\
\hline $21 / 082007$ & $84,74 \%$ & $79,02 \%$ \\
\hline 22082007 & $64,39 \%$ & $64,83 \%$ \\
\hline $23 / 082007$ & $81,99 \%$ & $73,60 \%$ \\
\hline $24 / 082007$ & $76,55 \%$ & $73,51 \%$ \\
\hline $27 / 082007$ & $88,55 \%$ & $72,68 \%$ \\
\hline $28 / 082007$ & $68,86 \%$ & $64,18 \%$ \\
\hline $29 / 082007$ & $75,73 \%$ & $66,54 \%$ \\
\hline $30 / 082007$ & $92,83 \%$ & $78,95 \%$ \\
\hline $31 / 082007$ & $63,20 \%$ & $62,97 \%$ \\
\hline
\end{tabular}

\begin{tabular}{|c|c|c|c|c|c|}
\hline \multicolumn{3}{|c|}{ Portfolio 5} & \multicolumn{3}{|c|}{ Portfolio 6} \\
\hline Date & Value & Growth & Date & Value & Growth \\
\hline $03 / 09 / 2007$ & $76,65 \%$ & $60,77 \%$ & $02 / 01 / 2008$ & $70,19 \%$ & $80,42 \%$ \\
\hline $04 / 00 / 2007$ & $78,21 \%$ & $66,86 \%$ & $03 / 01 / 2008$ & $80,82 \%$ & $86,63 \%$ \\
\hline $05 / 09 / 2007$ & $73,28 \%$ & $66,61 \%$ & $04 / 01 / 2008$ & $70,85 \%$ & $76,63 \%$ \\
\hline $06 / 09 / 2007$ & $73,83 \%$ & $67,10 \%$ & $07 / 01 / 2008$ & $77,71 \%$ & $70,85 \%$ \\
\hline $10 / 00 / 2007$ & $74,99 \%$ & $74,80 \%$ & $08 / 01 / 2008$ & $77,69 \%$ & $77,96 \%$ \\
\hline $11 / 09 / 2007$ & $70,39 \%$ & $73,80 \%$ & $09 / 01 / 2008$ & $63,34 \%$ & $73,69 \%$ \\
\hline $12 / 09 / 2007$ & $85,15 \%$ & $68,14 \%$ & $10 / 01 / 2008$ & $64,25 \%$ & $69,15 \%$ \\
\hline $13 / 09 / 2007$ & $77,69 \%$ & $73,96 \%$ & $11 / 01 / 2008$ & $63,18 \%$ & $75,82 \%$ \\
\hline $14 / 00 / 2007$ & $62,40 \%$ & $71,96 \%$ & $14 / 01 / 2008$ & $81,71 \%$ & $63,08 \%$ \\
\hline $17 / 08 / 2007$ & $67,86 \%$ & $79,51 \%$ & $15 / 01 / 2008$ & $69,21 \%$ & $76,72 \%$ \\
\hline $18 / 08 / 2007$ & $76,88 \%$ & $65,62 \%$ & $16 / 01 / 2008$ & $79,31 \%$ & $66,80 \%$ \\
\hline $19 / 09 / 2007$ & $76,55 \%$ & $69,96 \%$ & $17 / 01 / 2008$ & $75,21 \%$ & $69,49 \%$ \\
\hline $20 / 09 / 2007$ & $73,71 \%$ & $73,91 \%$ & $18 / 01 / 2008$ & $63,10 \%$ & $73,22 \%$ \\
\hline $21 / 09 / 2007$ & $71,96 \%$ & $72,83 \%$ & $21 / 01 / 2008$ & $67,67 \%$ & $62,67 \%$ \\
\hline $24 / 09 / 2007$ & ๓6,23\% & $85,25 \%$ & $22 / 01 / 2008$ & $72,64 \%$ & $79,33 \%$ \\
\hline $25 / 09 / 2007$ & $67,86 \%$ & $68,70 \%$ & $23 / 01 / 2008$ & $70,76 \%$ & $71,75 \%$ \\
\hline $26 / 09 / 2007$ & $79,73 \%$ & $74,09 \%$ & $24 / 01 / 2008$ & $71,76 \%$ & $59,80 \%$ \\
\hline $27 / 09 / 2007$ & $67,86 \%$ & $73,63 \%$ & $28 / 01 / 2008$ & $75,04 \%$ & $72,99 \%$ \\
\hline $28 / 09 / 2007$ & $68,73 \%$ & $62,34 \%$ & $29 / 01 / 2008$ & $79,24 \%$ & $71,07 \%$ \\
\hline $01 / 10 / 2007$ & $67,32 \%$ & $52,99 \%$ & $30 / 01 / 2008$ & $83,53 \%$ & $83,90 \%$ \\
\hline $02 / 10 / 2007$ & $60,25 \%$ & $71,62 \%$ & $31 / 01 / 2008$ & $74,86 \%$ & $64,13 \%$ \\
\hline $03 / 10 / 2007$ & $77,37 \%$ & $72,78 \%$ & $01 / @ / 2008$ & $64,35 \%$ & $71,45 \%$ \\
\hline $04 / 10 / 2007$ & $86,85 \%$ & $77,81 \%$ & $06 / @ / 2008$ & $60,38 \%$ & $71,72 \%$ \\
\hline $05 / 10 / 2007$ & $75,62 \%$ & $83,18 \%$ & $07 / @ / 2008$ & $82,68 \%$ & $77,17 \%$ \\
\hline $08 / 10 / 2007$ & $86,08 \%$ & $67,85 \%$ & $08 / @ / 2008$ & $71,66 \%$ & $76,12 \%$ \\
\hline $09 / 10 / 2007$ & $72,25 \%$ & $75,90 \%$ & $11 / \varrho / 2008$ & $60,65 \%$ & $75,80 \%$ \\
\hline $10 / 10 / 2007$ & ๘,75\% & $72,54 \%$ & $12 / @ / 2008$ & $63,27 \%$ & $77, \infty \%$ \\
\hline $11 / 10 / 2007$ & $76,58 \%$ & $75,24 \%$ & $13 / \propto 2 / 2008$ & $75,40 \%$ & $72,04 \%$ \\
\hline $15 / 10 / 2007$ & $64,72 \%$ & $72,21 \%$ & $14 / @ / 2008$ & $72,36 \%$ & $80,6 \%$ \\
\hline $16 / 10 / 2007$ & $67,87 \%$ & $78.29 \%$ & $15 / \propto 2 / 2008$ & $75,04 \%$ & $74,42 \%$ \\
\hline $17 / 10 / 2007$ & $72,85 \%$ & $78,56 \%$ & $18 / @ / 2008$ & $60,24 \%$ & $72,93 \%$ \\
\hline $18 / 10 / 2007$ & $81,08 \%$ & $84,26 \%$ & $19 / \propto 2 / 2008$ & $60,59 \%$ & $7274 \%$ \\
\hline $19 / 10 / 2007$ & $85,04 \%$ & $84,97 \%$ & $20 / \propto 2 / 2008$ & $66,18 \%$ & $78,18 \%$ \\
\hline $22 / 10 / 2007$ & $75,09 \%$ & $74,64 \%$ & $21 / \propto 2 / 2008$ & $66,65 \%$ & $69,18 \%$ \\
\hline $23 / 10 / 2007$ & $76,02 \%$ & $74,77 \%$ & $22 / @ / 2008$ & $81,18 \%$ & $82,15 \%$ \\
\hline $24 / 10 / 2007$ & $74,81 \%$ & $77,18 \%$ & $25 / @ / 2008$ & $66,02 \%$ & $72,56 \%$ \\
\hline $25 / 10 / 2007$ & $70,71 \%$ & $79,59 \%$ & $26 / @ / 2008$ & $65,85 \%$ & $68,15 \%$ \\
\hline $26 / 10 / 2007$ & $64,38 \%$ & $73,44 \%$ & $27 / @ / 2008$ & $71,33 \%$ & $68.76 \%$ \\
\hline $29 / 10 / 2007$ & $72,14 \%$ & $73,32 \%$ & $28 / \propto 2 / 2008$ & $70,00 \%$ & $62,47 \%$ \\
\hline $30 / 10 / 2007$ & $75,88 \%$ & $69,25 \%$ & $29 / \propto 2 / 2008$ & $75,30 \%$ & $65,25 \%$ \\
\hline $31 / 10 / 2007$ & $63,20 \%$ & $74,44 \%$ & $03 / 03 / 2008$ & $79,44 \%$ & $69,61 \%$ \\
\hline $01 / 11 / 2007$ & $6,80 \%$ & $76,45 \%$ & $04 / 03 / 2008$ & $67,52 \%$ & $77,89 \%$ \\
\hline $05 / 11 / 2007$ & $72,14 \%$ & $68,39 \%$ & $05 / 03 / 2008$ & $76,50 \%$ & $71,70 \%$ \\
\hline $06 / 11 / 2007$ & $77,03 \%$ & $70,50 \%$ & $06 / 03 / 2008$ & $83,23 \%$ & $73,37 \%$ \\
\hline $07 / 11 / 2007$ & $78,58 \%$ & $70,82 \%$ & $07 / 03 / 2008$ & $77,61 \%$ & $68,87 \%$ \\
\hline $08 / 11 / 2007$ & $88,31 \%$ & $75,90 \%$ & $10 / œ / 2008$ & $62,58 \%$ & $74,16 \%$ \\
\hline $09 / 11 / 2007$ & $81,75 \%$ & $72,74 \%$ & $11 / \propto 3 / 2008$ & $88,59 \%$ & $80,12 \%$ \\
\hline $12 / 11 / 2007$ & $80,27 \%$ & $8225 \%$ & $12 / \propto 3 / 2008$ & $73,90 \%$ & $76,42 \%$ \\
\hline $13 / 11 / 2007$ & $78,55 \%$ & $66,43 \%$ & $13 / 03 / 2008$ & $78,94 \%$ & $74,68 \%$ \\
\hline $14 / 11 / 2007$ & $67,69 \%$ & $64,93 \%$ & $14 / 03 / 2008$ & $75,41 \%$ & $75,24 \%$ \\
\hline $16 / 11 / 2007$ & $71,60 \%$ & $74,96 \%$ & $17 / œ / 2008$ & $80,85 \%$ & $70,77 \%$ \\
\hline $19 / 11 / 2007$ & $86,91 \%$ & $63,94 \%$ & $18 / 03 / 2008$ & $69,23 \%$ & $81,96 \%$ \\
\hline $21 / 11 / 2007$ & $83,43 \%$ & $73,42 \%$ & $19 / 03 / 2008$ & $81,65 \%$ & $78,75 \%$ \\
\hline $22 / 11 / 2007$ & $67,01 \%$ & $64,76 \%$ & $20 / 0 \beta / 2008$ & $78,78 \%$ & $83,6 \%$ \\
\hline $23 / 11 / 2007$ & $81,57 \%$ & $80,31 \%$ & $24 / 03 / 2008$ & $72,68 \%$ & $86,44 \%$ \\
\hline $26 / 11 / 2007$ & $75,39 \%$ & $73,86 \%$ & $25 / 03 / 2008$ & $66,42 \%$ & $78,6 \%$ \\
\hline $27 / 11 / 2007$ & $80,29 \%$ & $65,39 \%$ & $26 / œ / 2008$ & $67,07 \%$ & $81, € \%$ \\
\hline $28 / 11 / 2007$ & $72,95 \%$ & $82,92 \%$ & $27 / 03 / 2008$ & $63,02 \%$ & $80,40 \%$ \\
\hline $29 / 11 / 2007$ & $73,11 \%$ & $78,36 \%$ & $28 / 03 / 2008$ & $78,02 \%$ & $84,33 \%$ \\
\hline $30 / 11 / 2007$ & $62,39 \%$ & $63,67 \%$ & $31 / @ / 2008$ & $77,01 \%$ & $93,41 \%$ \\
\hline $03 / 12 / 2007$ & ๘,46\% & $71, \infty \%$ & $01 / 04 / 2008$ & $67,50 \%$ & $63,80 \%$ \\
\hline $04 / 12 / 2007$ & $84,52 \%$ & $69, \subset \%$ & $02 / 04 / 2008$ & $65,69 \%$ & $71,09 \%$ \\
\hline $05 / 12 / 2007$ & $67,25 \%$ & $76,62 \%$ & $03 / 04 / 2008$ & $58,02 \%$ & $6278 \%$ \\
\hline $06 / 12 / 2007$ & $63,82 \%$ & $67, \oplus \%$ & $04 / 04 / 2008$ & $70,42 \%$ & $64,47 \%$ \\
\hline $07 / 12 / 2007$ & $73,56 \%$ & $73,82 \%$ & $07 / 04 / 2008$ & $71,8 \% \%$ & $74,47 \%$ \\
\hline $10 / 12 / 2007$ & ๓, $45 \%$ & $66,93 \%$ & $08 / 04 / 2008$ & $80,39 \%$ & $65,35 \%$ \\
\hline $11 / 12 / 2007$ & $81,70 \%$ & $78,75 \%$ & $09 / 04 / 2008$ & $71,45 \%$ & $78,90 \%$ \\
\hline $12 / 12 / 2007$ & $\tilde{\infty}, 87 \%$ & $67,5 \%$ & $10 / 04 / 2008$ & $73,70 \%$ & $76,91 \%$ \\
\hline $13 / 12 / 2007$ & $\oplus, 77 \%$ & $73,64 \%$ & $11 / 04 / 2008$ & $74,72 \%$ & $77, \infty \%$ \\
\hline $14 / 12 / 2007$ & ๔,91\% & $81,44 \%$ & $14 / 04 / 2008$ & $76,59 \%$ & $71,71 \%$ \\
\hline $17 / 12 / 2007$ & $77,29 \%$ & $76,72 \%$ & $15 / 04 / 2008$ & $74,90 \%$ & $77,91 \%$ \\
\hline $18 / 12 / 2007$ & $79,99 \%$ & $70,34 \%$ & $16 / 04 / 2008$ & $66,94 \%$ & $64,22 \%$ \\
\hline $19 / 12 / 2007$ & $70,91 \%$ & $65,76 \%$ & $17 / 04 / 2008$ & $83,78 \%$ & $75,97 \%$ \\
\hline $20 / 12 / 2007$ & $57,29 \%$ & $71,48 \%$ & $18 / 04 / 2008$ & $78.50 \%$ & $71,63 \%$ \\
\hline $21 / 12 / 2007$ & ळ,54\% & $74,03 \%$ & $22 / 04 / 2008$ & $79,41 \%$ & $75,32 \%$ \\
\hline $26 / 12 / 2007$ & $\varpi 8,97 \%$ & $61,59 \%$ & $23 / 04 / 2008$ & $77,54 \%$ & $7296 \%$ \\
\hline $27 / 12 / 2007$ & $71,92 \%$ & $63,94 \%$ & $24 / 04 / 2008$ & $66,96 \%$ & $76.25 \%$ \\
\hline $28 / 12 / 2007$ & $78,87 \%$ & $79,58 \%$ & $25 / 04 / 2008$ & $63,27 \%$ & $76,77 \%$ \\
\hline & & & $28 / 04 / 2008$ & $75,78 \%$ & $71,13 \%$ \\
\hline & & & $29 / 04 / 2008$ & $78,99 \%$ & $78,99 \%$ \\
\hline & & & $30 / 04 / 2008$ & $62,74 \%$ & $66.30 \%$ \\
\hline
\end{tabular}

BBR, Braz. Bus. Rev. (Engl. ed., Online), 


\begin{tabular}{|c|c|c|}
\hline \multicolumn{3}{|c|}{ Foriteslies 7} \\
\hline Date & $\begin{array}{l}\text { Value } \\
\end{array}$ & Growth \\
\hline $02 / 05 / 2008$ & $61,14 \%$ & $59,44 \%$ \\
\hline $05 / 05 / 2008$ & $74,04 \%$ & $71,58 \%$ \\
\hline $06 / 05 / 2008$ & $69,07 \%$ & $62,65 \%$ \\
\hline $07 / 05 / 2008$ & $77,05 \%$ & $76,34 \%$ \\
\hline $08 / 05 / 2008$ & $86,09 \%$ & $73,48 \%$ \\
\hline $09 / 05 / 2008$ & $77,84 \%$ & $70,00 \%$ \\
\hline $12 / 05 / 2008$ & $66,59 \%$ & $74,33 \%$ \\
\hline $13 / 05 / 2008$ & $68,52 \%$ & $70,22 \%$ \\
\hline $14 / 05 / 2008$ & $72,21 \%$ & $77,63 \%$ \\
\hline $15 / 05 / 2008$ & $76,40 \%$ & $72,90 \%$ \\
\hline $16 / 05 / 2008$ & $63,25 \%$ & $\propto 6,56 \%$ \\
\hline $19 / 05 / 2008$ & $72,78 \%$ & $72,34 \%$ \\
\hline $2 \alpha 05 / 2008$ & $68,47 \%$ & $67,70 \%$ \\
\hline $21 / 05 / 2008$ & $66,26 \%$ & $75,89 \%$ \\
\hline $23 / 05 / 2008$ & $77,21 \%$ & $77,71 \%$ \\
\hline $26 / 05 / 2008$ & $74,26 \%$ & $\varpi, 30 \%$ \\
\hline $27 / 05 / 2008$ & $79,48 \%$ & $77,74 \%$ \\
\hline $28 / 05 / 2008$ & $71,81 \%$ & $74,98 \%$ \\
\hline $29 / 05 / 2008$ & $82,11 \%$ & $76,10 \%$ \\
\hline $30 / 05 / 2008$ & $81,85 \%$ & $70,67 \%$ \\
\hline $02 / 06 / 2008$ & $90,00 \%$ & $97,39 \%$ \\
\hline $03 / 06 / 2008$ & $97,30 \%$ & $99,01 \%$ \\
\hline $04 / 06 / 2008$ & $100,00 \%$ & $97,42 \%$ \\
\hline $05 / 06 / 2008$ & $96,29 \%$ & $96,12 \%$ \\
\hline $0606 / 2008$ & $88,73 \%$ & $96,96 \%$ \\
\hline $09 / 06 / 2008$ & $80,00 \%$ & $89,65 \%$ \\
\hline $1006 / 2008$ & $97,60 \%$ & $86,22 \%$ \\
\hline $11 / 06 / 2008$ & $80,00 \%$ & $85,91 \%$ \\
\hline $12 / 06 / 2008$ & $80,00 \%$ & $79,02 \%$ \\
\hline $13 / 06 / 2008$ & $90,00 \%$ & $9 Q, 29 \%$ \\
\hline $1606 / 2008$ & $96,84 \%$ & $94,69 \%$ \\
\hline $17 / 06 / 2008$ & $90,00 \%$ & $86,24 \%$ \\
\hline $18 / 06 / 2008$ & $9283 \%$ & $83,87 \%$ \\
\hline $19 / 06 / 2008$ & $80,00 \%$ & $99,13 \%$ \\
\hline $20 / 06 / 2008$ & $90,00 \%$ & $86,88 \%$ \\
\hline $23 / 06 / 2008$ & $100,00 \%$ & $94,14 \%$ \\
\hline $24 / 06 / 2008$ & $100,00 \%$ & $97,78 \%$ \\
\hline $25 / 06 / 2008$ & $80,00 \%$ & $86,33 \%$ \\
\hline $2606 / 2008$ & $80,00 \%$ & $80,25 \%$ \\
\hline $27 / 06 / 2008$ & $100,00 \%$ & $100,00 \%$ \\
\hline $30,06 / 2008$ & $80,00 \%$ & $9 Q, 16 \%$ \\
\hline $01 / 07 / 2008$ & $80,00 \%$ & $85,94 \%$ \\
\hline $02 / 07 / 2008$ & $90,00 \%$ & $90,00 \%$ \\
\hline $03 / 07 / 2008$ & $90,00 \%$ & $97,06 \%$ \\
\hline $04 / 07 / 2008$ & $99,93 \%$ & $98,89 \%$ \\
\hline $07 / 07 / 2008$ & $93,06 \%$ & $96,87 \%$ \\
\hline $08 / 07 / 2008$ & $100,00 \%$ & $100,00 \%$ \\
\hline $10 / 07 / 2008$ & $80,00 \%$ & $91,62 \%$ \\
\hline $11 / 07 / 2008$ & $80,00 \%$ & $90,00 \%$ \\
\hline $14 / 07 / 2008$ & $86,25 \%$ & $98,02 \%$ \\
\hline $15 / 07 / 2008$ & $83,59 \%$ & $83,21 \%$ \\
\hline $1607 / 2008$ & $80,00 \%$ & $96,47 \%$ \\
\hline $17 / 07 / 2008$ & $100,00 \%$ & $93,20 \%$ \\
\hline $1807 / 2008$ & $100,00 \%$ & $100,00 \%$ \\
\hline $21 / 07 / 2008$ & $96,14 \%$ & $90,00 \%$ \\
\hline $22107 / 2008$ & $80,00 \%$ & $100,00 \%$ \\
\hline $23 / 07 / 2008$ & $77,43 \%$ & $90,00 \%$ \\
\hline $24 / 07 / 2008$ & $90,00 \%$ & $98,15 \%$ \\
\hline $25 / 07 / 2008$ & $85,40 \%$ & $90,00 \%$ \\
\hline $2807 / 2008$ & $88,94 \%$ & $100,00 \%$ \\
\hline $29 / 07 / 2008$ & $78,58 \%$ & $80,00 \%$ \\
\hline $3007 / 2008$ & $79,58 \%$ & $90,00 \%$ \\
\hline $31 / 07 / 2008$ & $80,00 \%$ & $90,00 \%$ \\
\hline $01 / 08 / 2008$ & $70,00 \%$ & $90,00 \%$ \\
\hline $04 / 08 / 2008$ & $80,00 \%$ & $94,12 \%$ \\
\hline $05108 / 2008$ & $70,00 \%$ & $50,00 \%$ \\
\hline $0608 / 2008$ & $90,00 \%$ & $100,00 \%$ \\
\hline $07 / 08 / 2008$ & $80,00 \%$ & $100,00 \%$ \\
\hline $0808 / 2008$ & $90,00 \%$ & $80,00 \%$ \\
\hline $11 / 08 / 2008$ & $100,00 \%$ & $90,00 \%$ \\
\hline $12 / 08 / 2008$ & $70,00 \%$ & $100,00 \%$ \\
\hline $13 / 08 / 2008$ & $89,33 \%$ & $98,20 \%$ \\
\hline $14 / 08 / 2008$ & $90,00 \%$ & $80,00 \%$ \\
\hline $15 / 08 / 2008$ & $90,00 \%$ & $77,96 \%$ \\
\hline $18 / 08 / 2008$ & $90,00 \%$ & $80,00 \%$ \\
\hline $19 / 08 / 2008$ & $79,55 \%$ & $90,00 \%$ \\
\hline $2008 / 2008$ & $80,00 \%$ & $100,00 \%$ \\
\hline $21 / 08 / 2008$ & $70,00 \%$ & $96,99 \%$ \\
\hline $22 / 08 / 2008$ & $70,00 \%$ & $80,00 \%$ \\
\hline $25 / 08 / 2008$ & $100,00 \%$ & $74,28 \%$ \\
\hline $26 / 08 / 2008$ & $80,00 \%$ & $86,89 \%$ \\
\hline $27 / 08 / 2008$ & $90,00 \%$ & $85,65 \%$ \\
\hline $28 / 08 / 2008$ & $100,00 \%$ & $98,76 \%$ \\
\hline $29 / 08 / 2008$ & $90,00 \%$ & $79,77 \%$ \\
\hline
\end{tabular}

\begin{tabular}{|c|c|c|}
\hline \multicolumn{3}{|c|}{ Partfolio 0} \\
\hline Date & Value & Growth \\
\hline $01 / 09 / 2008$ & $68,24 \%$ & $90,00 \%$ \\
\hline $02 / 09 / 2008$ & $74,08 \%$ & $99,45 \%$ \\
\hline $03 / 09 / 2008$ & $79,95 \%$ & $99,96 \%$ \\
\hline $04 / 09 / 2008$ & $75,60 \%$ & $99,38 \%$ \\
\hline $05 / 09 / 2008$ & $80,80 \%$ & $90,00 \%$ \\
\hline $08 / 09 / 2008$ & $54,91 \%$ & $91,96 \%$ \\
\hline $09 / 09 / 2008$ & $87,25 \%$ & $90,00 \%$ \\
\hline $10 / 09 / 2008$ & $56,23 \%$ & $100,00 \%$ \\
\hline $11 / 09 / 2008$ & $76,18 \%$ & $90,00 \%$ \\
\hline $12 / 09 / 2008$ & $77,68 \%$ & $90,00 \%$ \\
\hline $15 / 09 / 2008$ & $85,58 \%$ & $94,84 \%$ \\
\hline $16 / 09 / 2008$ & $97,85 \%$ & $100,00 \%$ \\
\hline $17 / 09 / 2008$ & $76,06 \%$ & $87,09 \%$ \\
\hline $18 / 09 / 2008$ & $71,41 \%$ & $88,11 \%$ \\
\hline $19 / 09 / 2008$ & $69,94 \%$ & $79,42 \%$ \\
\hline $22 / 09 / 2008$ & $76,79 \%$ & $90,00 \%$ \\
\hline $23 / 09 / 2008$ & $96,09 \%$ & $80,00 \%$ \\
\hline $24 / 09 / 2008$ & $83,66 \%$ & $73,24 \%$ \\
\hline $25 / 09 / 2008$ & $75,04 \%$ & $88,39 \%$ \\
\hline $26 / 09 / 2008$ & $72,26 \%$ & $96,76 \%$ \\
\hline $29 / 09 / 2008$ & $87,49 \%$ & $86,91 \%$ \\
\hline $30 / 09 / 2008$ & $90,00 \%$ & $100,00 \%$ \\
\hline $01 / 10 / 2008$ & $90,00 \%$ & $80,00 \%$ \\
\hline $02 / 10 / 2008$ & $80,00 \%$ & $98,78 \%$ \\
\hline $03 / 10 / 2008$ & $100,00 \%$ & $94,37 \%$ \\
\hline $06 / 10 / 2008$ & $69,17 \%$ & $99,43 \%$ \\
\hline $07 / 10 / 2008$ & $99,38 \%$ & $90,00 \%$ \\
\hline $08 / 10 / 2008$ & $86,92 \%$ & $89,84 \%$ \\
\hline $09 / 10 / 2008$ & $85,33 \%$ & $97,29 \%$ \\
\hline $10 / 10 / 2008$ & $78,44 \%$ & $84,95 \%$ \\
\hline $13 / 10 / 2008$ & $99,56 \%$ & $90,00 \%$ \\
\hline $14 / 10 / 2008$ & $78,62 \%$ & $94,21 \%$ \\
\hline $15 / 10 / 2008$ & $97,50 \%$ & $97,37 \%$ \\
\hline $16 / 10 / 2008$ & $90,00 \%$ & $90,00 \%$ \\
\hline $17 / 10 / 2008$ & $70,00 \%$ & $89,38 \%$ \\
\hline $20 / 10 / 2008$ & $79,14 \%$ & $82,74 \%$ \\
\hline $21 / 10 / 2008$ & $86,98 \%$ & $98,88 \%$ \\
\hline $22 / 10 / 2008$ & $95,33 \%$ & $96,25 \%$ \\
\hline $23 / 10 / 2008$ & $79,46 \%$ & $96,22 \%$ \\
\hline $24 / 10 / 2008$ & $89,80 \%$ & $97,99 \%$ \\
\hline $27 / 10 / 2008$ & $96,72 \%$ & $96,51 \%$ \\
\hline $28 / 10 / 2008$ & $78,48 \%$ & $100,00 \%$ \\
\hline $29 / 10 / 2008$ & $88,83 \%$ & $90,00 \%$ \\
\hline $30 / 10 / 2008$ & $96,94 \%$ & $90,91 \%$ \\
\hline $31 / 10 / 2008$ & $100,00 \%$ & $88.28 \%$ \\
\hline $03 / 11 / 2008$ & $95,43 \%$ & $97,38 \%$ \\
\hline $04 / 11 / 2008$ & $98,98 \%$ & $89,80 \%$ \\
\hline $05 / 11 / 2008$ & $89,84 \%$ & $98,79 \%$ \\
\hline $06 / 11 / 2008$ & $97,94 \%$ & $100,00 \%$ \\
\hline $07 / 11 / 2008$ & $93,88 \%$ & $90,00 \%$ \\
\hline $10 / 11 / 2008$ & $90,00 \%$ & $96,36 \%$ \\
\hline $11 / 11 / 2008$ & $99,98 \%$ & $88,73 \%$ \\
\hline $12 / 11 / 2008$ & $89,34 \%$ & $80,00 \%$ \\
\hline $13 / 11 / 2008$ & $86,60 \%$ & $96,13 \%$ \\
\hline $14 / 11 / 2008$ & $73,97 \%$ & $93,52 \%$ \\
\hline $17 / 11 / 2008$ & $89,10 \%$ & $84,49 \%$ \\
\hline $18 / 11 / 2008$ & $92,65 \%$ & $9 Q, 60 \%$ \\
\hline $19 / 11 / 2008$ & $77,68 \%$ & $79,14 \%$ \\
\hline $21 / 11 / 2008$ & $73,87 \%$ & $94,02 \%$ \\
\hline $24 / 11 / 2008$ & $87,29 \%$ & $96,00 \%$ \\
\hline $25 / 11 / 2008$ & $93,47 \%$ & $96,53 \%$ \\
\hline $26 / 11 / 2008$ & $95,57 \%$ & $100,00 \%$ \\
\hline $27 / 11 / 2008$ & $96,75 \%$ & $88,04 \%$ \\
\hline $28 / 11 / 2008$ & $94,34 \%$ & $84,11 \%$ \\
\hline $01 / 12 / 2008$ & $98,72 \%$ & $80,00 \%$ \\
\hline $02 / 12 / 2008$ & $93,66 \%$ & $98,26 \%$ \\
\hline $03 / 12 / 2008$ & $72,71 \%$ & $90,00 \%$ \\
\hline $04 / 12 / 2008$ & $87,35 \%$ & $78,52 \%$ \\
\hline $05 / 12 / 2008$ & $96,11 \%$ & $9 Q, 86 \%$ \\
\hline $08 / 12 / 2008$ & $100,00 \%$ & $87,39 \%$ \\
\hline $09 / 12 / 2008$ & $70,00 \%$ & $96,55 \%$ \\
\hline $10 / 12 / 2008$ & $85,45 \%$ & $89,22 \%$ \\
\hline $11 / 12 / 2008$ & $95,92 \%$ & $97,01 \%$ \\
\hline $12 / 12 / 2008$ & $90,00 \%$ & $79,28 \%$ \\
\hline $15 / 12 / 2008$ & $85,29 \%$ & $96,88 \%$ \\
\hline $16 / 12 / 2008$ & $89,78 \%$ & $96,86 \%$ \\
\hline $17 / 12 / 2008$ & $87,37 \%$ & $87,55 \%$ \\
\hline $18 / 12 / 2008$ & $93,01 \%$ & $84,95 \%$ \\
\hline $19 / 12 / 2008$ & $84,42 \%$ & $96,70 \%$ \\
\hline $22 / 12 / 2008$ & $96,32 \%$ & $96,01 \%$ \\
\hline $23 / 12 / 2008$ & $64,65 \%$ & $89,34 \%$ \\
\hline $26 / 12 / 2008$ & $77,33 \%$ & $90,25 \%$ \\
\hline $29 / 12 / 2008$ & $81,67 \%$ & $82,53 \%$ \\
\hline $30 / 12 / 2008$ & $93,72 \%$ & $94,66 \%$ \\
\hline
\end{tabular}

\begin{tabular}{|c|c|c|}
\hline \multicolumn{3}{|c|}{ Portfolio 9} \\
\hline Date & Value & Growth \\
\hline$\propto / 01 / 2009$ & $75,48 \%$ & $86,93 \%$ \\
\hline $06 / 01 / 2009$ & $99,50 \%$ & $81,60 \%$ \\
\hline $06 / 01 / 2009$ & $100,00 \%$ & $87,02 \%$ \\
\hline $07 / 01 / 2009$ & $100,00 \%$ & $89,54 \%$ \\
\hline $08 / 01 / 2009$ & $87,50 \%$ & $9 Q, 85 \%$ \\
\hline $09 / 01 / 2009$ & $88,26 \%$ & $93,94 \%$ \\
\hline $12 / 01 / 2009$ & $98,68 \%$ & $9 \mathrm{Q}, 85 \%$ \\
\hline $13 / 01 / 2009$ & $97,34 \%$ & $77,25 \%$ \\
\hline $14 / 01 / 2009$ & $90,00 \%$ & $88,37 \%$ \\
\hline $15 / 01 / 2009$ & $96,22 \%$ & $94,02 \%$ \\
\hline $16 / 01 / 2009$ & $89,61 \%$ & $80,55 \%$ \\
\hline $19 / 01 / 2009$ & $79,83 \%$ & $91,76 \%$ \\
\hline $20 / 01 / 2009$ & $96,94 \%$ & $91,81 \%$ \\
\hline $21 / 01 / 2009$ & $87,67 \%$ & $81,91 \%$ \\
\hline $22 / 01 / 2009$ & $96,16 \%$ & $82,78 \%$ \\
\hline $23 / 01 / 2009$ & $84,94 \%$ & $70,66 \%$ \\
\hline $26 / 01 / 2009$ & $79,45 \%$ & $88,11 \%$ \\
\hline $27 / 01 / 2009$ & $85,89 \%$ & $89,88 \%$ \\
\hline $28 / 01 / 2009$ & $76,93 \%$ & $86,50 \%$ \\
\hline $29 / 01 / 2009$ & $98,73 \%$ & $78,12 \%$ \\
\hline $30 / 01 / 2009$ & $90,00 \%$ & $91,64 \%$ \\
\hline$@ / @ / 2009$ & $97,31 \%$ & $89,07 \%$ \\
\hline @/@/2009 & $88,75 \%$ & $83,93 \%$ \\
\hline $04 / @ 2 / 2009$ & $87,24 \%$ & $84,52 \%$ \\
\hline $06 / @ / 2009$ & $94,17 \%$ & $83,27 \%$ \\
\hline $06 / @ / 2009$ & $61,31 \%$ & $84,27 \%$ \\
\hline $09 / @ 2 / 2009$ & $87,64 \%$ & $81,10 \%$ \\
\hline $10 / @ / 2009$ & $89,82 \%$ & $79,19 \%$ \\
\hline $11 / @ / 2009$ & $89,71 \%$ & $88,87 \%$ \\
\hline $12 / @ / 2009$ & $85,46 \%$ & $85,30 \%$ \\
\hline $13 / @ 2 / 2009$ & $71,55 \%$ & $85,15 \%$ \\
\hline $16 / @ / 2009$ & $84,30 \%$ & $80,04 \%$ \\
\hline $17 / @ / 2009$ & $93,98 \%$ & $89,51 \%$ \\
\hline $18 / @ 2 / 2009$ & $96,74 \%$ & $89,25 \%$ \\
\hline $19 / @ / 2009$ & $\llbracket 2,86 \%$ & $87,11 \%$ \\
\hline $20 / @ / 2009$ & $87,59 \%$ & $90,92 \%$ \\
\hline $25 / @ / 2009$ & $100,00 \%$ & $93,72 \%$ \\
\hline $26 / @ / 2009$ & $64,83 \%$ & $73,62 \%$ \\
\hline $27 / @ / 2009$ & $85,01 \%$ & $86,68 \%$ \\
\hline @/ @3/2009 & $54,76 \%$ & $80,15 \%$ \\
\hline $03 / 03 / 2009$ & $82,98 \%$ & $70,95 \%$ \\
\hline $04 / 03 / 2009$ & $90,72 \%$ & $90,05 \%$ \\
\hline $06 / 03 / 2009$ & $89,40 \%$ & $63,53 \%$ \\
\hline $06 / 03 / 2009$ & $73,13 \%$ & $92,46 \%$ \\
\hline $09 / 03 / 2009$ & $71,92 \%$ & $67,76 \%$ \\
\hline $10 / 03 / 2009$ & $75,27 \%$ & $77,19 \%$ \\
\hline $11 / 03 / 2009$ & $79,82 \%$ & $85,53 \%$ \\
\hline $12 / 03 / 2009$ & $75,17 \%$ & $87,26 \%$ \\
\hline $13 / 03 / 2009$ & $81,46 \%$ & $89,82 \%$ \\
\hline $16 / 03 / 2009$ & $96,07 \%$ & $89,85 \%$ \\
\hline $17 / 03 / 2009$ & $82,09 \%$ & $86,57 \%$ \\
\hline $18 / 03 / 2009$ & $90,08 \%$ & $88,47 \%$ \\
\hline $19 / 03 / 2009$ & $85,64 \%$ & $71,11 \%$ \\
\hline $20 / 00 / 2009$ & $86,67 \%$ & $87,46 \%$ \\
\hline $23 / 03 / 2009$ & $83,26 \%$ & $88,20 \%$ \\
\hline $24 / 03 / 2009$ & $87,19 \%$ & $73,51 \%$ \\
\hline $25 / 03 / 2009$ & $96,69 \%$ & $79,76 \%$ \\
\hline $26 / 03 / 2009$ & $83,23 \%$ & $84,84 \%$ \\
\hline $27 / 03 / 2009$ & $94,59 \%$ & $78,44 \%$ \\
\hline $30 / 03 / 2009$ & $90,41 \%$ & $85,22 \%$ \\
\hline $31 / 03 / 2009$ & $71,41 \%$ & $70,76 \%$ \\
\hline $01 / 04 / 2009$ & $82,23 \%$ & $86,73 \%$ \\
\hline$\propto / 04 / 2009$ & $62,57 \%$ & $88,80 \%$ \\
\hline $03 / 04 / 2009$ & $73,80 \%$ & $87,77 \%$ \\
\hline $06 / 04 / 2009$ & $76,79 \%$ & $87,77 \%$ \\
\hline $07 / 04 / 2009$ & $72,40 \%$ & $84,25 \%$ \\
\hline $08 / 04 / 2009$ & $75,37 \%$ & $91,94 \%$ \\
\hline $09 / 04 / 2009$ & $89,98 \%$ & $90,25 \%$ \\
\hline $13 / 04 / 2009$ & $75,13 \%$ & $76,10 \%$ \\
\hline $14 / 04 / 2009$ & $79,44 \%$ & $88,35 \%$ \\
\hline $15 / 04 / 2009$ & $86,68 \%$ & $91,33 \%$ \\
\hline $16 / 04 / 2009$ & $82,79 \%$ & $86,68 \%$ \\
\hline $17 / 04 / 2009$ & $80,30 \%$ & $77,81 \%$ \\
\hline $20 / 04 / 2009$ & $63,74 \%$ & $88,67 \%$ \\
\hline $22 / 04 / 2009$ & $76,83 \%$ & $74,77 \%$ \\
\hline $23 / 04 / 2009$ & $74,14 \%$ & $59,53 \%$ \\
\hline $24 / 04 / 2009$ & $75,84 \%$ & $89,56 \%$ \\
\hline $27 / 04 / 2009$ & $88,41 \%$ & $87,66 \%$ \\
\hline $28 / 04 / 2009$ & $89,45 \%$ & $\approx 6,72 \%$ \\
\hline $29 / 04 / 2009$ & $78,91 \%$ & $86,80 \%$ \\
\hline $30 / 04 / 2009$ & $77,64 \%$ & $87,08 \%$ \\
\hline
\end{tabular}

BBR, Braz. Bus. Rev. (Engl. ed., Online), 


\footnotetext{
${ }^{i}$ Basu (1977), Fama \& French (1992), Sharpe et al. (1993), Lakonishok, Shleifer \& Vishny (1994), Chan, Jegadeesh \& Lakonishok (1995), Haugen (1995), Haugen \& Baker (1996) and Fama \& French (1998).

${ }^{\text {ii }}$ Hazzan (1991), Costa Jr. \& Neves (2000), Ramos, Picanço \& Costa Jr (2000), Nagano, Merlo \& Silva (2003), Rostagno, Soares \& Soares (2003), Lopes \& Galdi (2007), and Lucena et al. (2008).

${ }^{\text {iii }}$ Smith \& Whaley (1994) showed that the estimates of this spread based on serial covariance are negatively biased. Furthermore, according to Gwilym \& Thomas (2002), these estimates can also be biased due to the noise present in the data.

${ }^{\text {iv }}$ On the BM\&FBovespa, although the presence of market makers is permitted, and even encouraged, the most liquid shares do not have such a specialist. We used these stocks so that the results would not be influenced by liquidity. Besides this, in forming the portfolios, we always used shares that are included in the Ibovespa, for the same reason (see Section 3).

${ }^{v}$ Section 2.2.1 contains details of our estimation of the bid-ask spread and the information asymmetry component.

vi The annualized volatilities were calculated here by the standard deviation of the daily returns multiplied by the square root of 252

vii The standard deviation of the volatilities of the value portfolio is $12 \%$, while the figure for the growth portfolio is $14 \%$.

viii According to the procedure of Fama \& French (1993), each year the stocks are classified into two groups,

with the same numbers of stocks, by the size criterion (value of the stock multiplied by the number of stocks), with the $\mathrm{S}$ group containing those with smaller values and the B group containing those with bigger values. The stocks are also divided into three groups according to the ratio between the book and market value (BV/MV), with the lowest $30 \%$ assigned $\mathrm{L}$ low, the middle $40 \% \mathrm{M}$ and the highest $30 \% \mathrm{H}$.
} 